\title{
Sorting of Internalized Neurotrophins into an Endocytic Transcytosis Pathway via the Golgi System: Ultrastructural Analysis in Retinal Ganglion Cells
}

\author{
Rafal Butowt and Christopher S. von Bartheld \\ Department of Physiology and Cell Biology, University of Nevada School of Medicine, Reno, Nevada 89557
}

Subcellular pathways and accumulation of internalized radiolabeled neurotrophins NGF, BDNF, and NT-3 were examined in retinal ganglion cells (RGCs) of chick embryos by using quantitative electron microscopic autoradiography. All three neurotrophins accumulated in endosomes and multivesicular bodies. BDNF and NGF also concentrated at the plasma membrane, whereas NT-3 accumulated transiently in the Golgi system. The enhanced targeting of NT-3 to the Golgi system correlated with the anterograde axonal transport of this neurotrophin. Anterograde transport of NT-3, but not its internalization, was significantly attenuated by the tyrosine kinase (trk) inhibitor K252a. Abolishment of trk activity with K252a shifted NT-3 (and BDNF) away from the Golgi system and into a lysosomal pathway, indicating that trk activity regulated sorting of the ligand-receptor complex. Cross-linking of neurotrophins and immunoprecipitation with antibodies to the neurotrophin receptors $\mathrm{p} 75$, trkA, trkB, and trkC showed that the large majority of exogenous, receptor-bound NT-3 was bound to trkC in RGC somata, but during anterograde transport in the optic nerve most receptor-bound NT-3 was associated with p75, and after arrival and release in the optic tectum transferred to presumably postsynaptic trkC. These results reveal remarkable and unexpected differences in the intracellular pathways and fates of different neurotrophins within the same cell type. They provide first evidence for an endocytic pathway of internalized neurotrophic factors via the Golgi system before anterograde transport and transcytosis. The results challenge the belief that after internalization all neurotrophins are rapidly degraded in lysosomes.

Key words: anterograde transport; BDNF; NT-3; NGF; trkB; trkC; p75 neurotrophin receptor; neurotrophic factor; visual system; internalization; degradation; K252a; Golgi; lysosome; sorting; retina
Nothing is known about the subcellular pathways and organelles that contain the internalized neurotrophins BDNF and NT-3, despite significant advances in the identification of downstream targets of neurotrophins and cascades of signal transduction (Segal and Greenberg, 1996; Riccio et al., 1997; Kaplan and Miller, 2000). Most of the internalized NGF appears to be targeted to lysosomes and is rapidly degraded (Schwab and Thoenen, 1977; Johnson et al., 1978; Claude et al., 1982; Hogue-Angeletti et al., 1982; Rohrer et al., 1982; Layer and Shooter, 1983; Stieber et al., 1984; Eveleth and Bradshaw, 1992; Ure and Campenot, 1997) (but see Bernd and Greene, 1983). These studies suggested a rather simple model of termination of trophic action, namely the rapid degradation of the neurotrophin after delivery of the trophic signal.

Recent studies have suggested a more complex fate of internalized neurotrophins. The neurotrophins BDNF and NT-3 can avoid the degradation pathway and can be targeted for release or for packaging in vesicles for anterograde axonal transport after internalization (von Bartheld et al., 2001). The subcellular trafficking of trophic factor-receptor complexes in neurons is unknown but likely includes sorting in endosomes, an endocytic

Received March 12, 2001; revised Aug. 28, 2001; accepted Sept. 4, 2001.

The work was supported by National Institutes of Health Grants NS 35931 and NS 35931-02S1 (C.S.V.). Antibodies were kindly provided by Louis Reichardt, Doug Clary, Frances Lefcort, Gisela Weskamp, (anti-p75, trkB, and trkC), and Peter Jeffrey (anti-Thy1); trkB and trkC probes were provided by Reg Williams (Karolinska); and human recombinant BDNF, NT-3, and NT-4 were provided by Ronald Lindsay (Regeneron). We thank Mark Bothwell, Margaret Byers, Susana CohenCory, Howard Rind, and Les Westrum for advice.

Correspondence should be addressed to Christopher von Bartheld, Department of Physiology and Cell Biology, Mailstop 352, University of Nevada School of Medicine, Reno, NV 89557. E-mail: chrisvb@physio.unr.edu.

Copyright (C) 2001 Society for Neuroscience 0270-6474/01/218915-16\$15.00/0 pathway to the Golgi system (Green and Kelly, 1992; Sandvig and van Deurs, 1996; Mukherjee et al., 1997), followed by packaging in vesicles for anterograde axonal transport (Hurtley, 1993; Fawcett et al., 1997; Michael et al., 1997).

Retinal ganglion cells (RGCs) are an excellent model system for trafficking studies, because their environment can be well controlled in vivo, yet they are typical CNS neurons, unlike other model system neurons such as dorsal root ganglia, which lack normal dendrites and afferent input. Developing chick RGCs express the neurotrophin receptors $\mathrm{p} 75$, trkB, and trkC but not trkA (von Bartheld, 1998a), and they internalize NGF, BDNF, and NT-3. Internalized NT-3 is transported anterogradely much more efficiently than BDNF in this system (von Bartheld et al., 1996a). Likewise, endogenous neurotrophins are differentially sorted in chick RGCs, with NT-3, but very little BDNF, destined for anterograde transport (von Bartheld and Butowt, 2000). Taken together, these studies indicate that neurotrophins are targeted to different domains within neurons and that internalized neurotrophins are not necessarily degraded after internalization.

Here we show that NGF, BDNF, and NT-3 follow different intracellular pathways in RGCs after internalization and that their sorting is regulated at least in part by tyrosine kinase activity. Consistent with its anterograde transport, NT-3 accumulated in the Golgi system, whereas BDNF was prevalent at the plasma membrane. When trk kinase activity was blocked with K252a, anterograde transport of NT-3, but not its internalization, was reduced, and its distribution was shifted from the Golgi to lysosomal pathways. A significant fraction of the anterogradely transported NT-3 bound to neurotrophin receptors during transport, with both trkC and p75 playing roles as presumptive trans- 
porters. Internalized neurotrophins are differentially sorted, presumably reflecting their complex functions as factors promoting survival, differentiation, dendritic growth, and synaptic plasticity.

Preliminary data have been published previously in abstract form (von Bartheld, 1996; Butowt and von Bartheld, 2000).

\section{MATERIALS AND METHODS}

Sources of materials. Polyclonal antibodies to chicken trkA, trkB, and trkC (against the extracellular domain) were from Louis Reichardt, Frances Lefcort and Doug Clary (Lefcort et al., 1996; von Bartheld et al., 1996b), and antibodies to chicken p75 neurotrophin receptor (ChEX, Weskamp and Reichardt, 1991) were from Gisela Weskamp and Louis Reichardt (Howard Hughes Medical Institute, San Francisco, CA). For RGC purification, monoclonal antibodies to Thy1 (IgG SB1-20.1) (French and Jeffrey, 1986) were obtained from Peter Jeffrey (Sydney, Australia). Human recombinant BDNF, NT-3, and NT-4 were provided by Ron Lindsay (Regeneron, Tarrytown, NY). Mouse NGF was a gift from Mark Bothwell (University of Washington, Seattle, WA) or purchased from Alomone Labs (Jerusalem, Israel). Glial cell line-derived neurotrophic factor (GDNF) and cardiotrophin-1 (CT-1) were from PeproTech (Rocky Hill, NJ). Brefeldin A, cytochrome c, monensin, wortmannin, and secondary anti-chicken antibody (M8645) were from Sigma (St. Louis, MO), Ilford L4 emulsion was from Polysciences (Warrington, PA), K252a was from Alomone Labs, and the PI3-kinase inhibitor LY294,002 was from Alexis Corp (San Diego, CA). The crosslinkers 1-ethyl-3 (3-dimethylaminopropyl) carbodiimide-HCl (EDC) and disuccinimidyl suberate (DSS) were from Pierce (Rockford, IL). Chicken eggs were obtained from California Golden Eggs (Sacramento, CA) and were incubated in humidified incubators at $37.5-38^{\circ} \mathrm{C}$. Approximately 1050 chicken eggs were used. The ages of chick embryos were verified at the time they were killed according to Hamburger and Hamilton (1951). Experimental procedures were conducted in compliance with the Policy on the Use of Animals in Neuroscience Research and were approved by the local animal care committee.

Radio-iodination and intraocular injections. Neurotrophins and cytochrome $c$ were iodinated with lactoperoxidase as described (Vale and Shooter, 1985; von Bartheld, 2001). Na-I ${ }^{125}$ was purchased from NEN Life Science Products (Boston, MA). Incorporations were 47-86.5\% (NGF), 91-95.9\% (BDNF), 79.7-92.7\% (NT-3), 41.3-60.7\% (cytochrome c), 64.5-89.8\% (GDNF), and 95.0\% (CT-1). Specific activities were $61-109 \mathrm{cpm} / \mathrm{pg}$ NGF, $90-196.6 \mathrm{cpm} / \mathrm{pg}$ BDNF, $70.6-197.3 \mathrm{cpm} / \mathrm{pg}$ NT-3, 42-118.6 cpm/pg cytochrome $c, 168-333 \mathrm{cpm} / \mathrm{pg}$ GDNF, and 32.4 $\mathrm{cpm} / \mathrm{pg}$ CT-1. For transport studies, free iodide was removed from the preparation when the incorporation was $\leq 90 \%$, and for ultrastructural analysis of internalization it was removed when incorporation was $\leq 95 \%$. Iodinated neurotrophins were used within $12 \mathrm{~d}$ after iodination. They migrated in $15 \%$ SDS-PAGE as single bands at $\sim 13-14 \mathrm{kDa}$ and were transported in a receptor-mediated fashion (von Bartheld et al., 1996a). Twenty hours after injections, the embryos were anesthetized with Nembutal, perfused with $4 \%$ paraformaldehyde (PFA), staged, and postfixed. The amount of radioactivity in the dissected eyes and midbrains [embryonic day (E) 15-17] was measured in a gamma counter. The ratios of the activity in the midbrain/eye were determined for each animal and averaged for the different treatment groups. SEs were calculated and the data plotted as a function of the doses injected. The brains and the eyes were embedded in paraffin, and four series of sections (10 $\mu \mathrm{m}$ thickness) through the midbrain at the level of the isthmo-optic nucleus were collected on glass slides and exposed on x-ray film for 2-5 d, and the sections were coated with NTB-2 emulsion (Kodak, Rochester, NY). Sections were exposed for $3-8$ weeks at $4^{\circ} \mathrm{C}$, were lightly counterstained with thionin after development, and coverslipped. After injections of iodinated proteins into the retina or into the tectum, the amount of radioactivity in the eyes was measured in a gamma counter.

Compounds were injected into chick embryo eyes in volumes of 5-10 $\mu \mathrm{l}$ (von Bartheld, 1998b). Coinjection procedures with radiolabeled neurotrophins or cytochrome $c$ included monensin $(9 \mu \mathrm{g})$, excess cold NT-3 (1-3 $\mu \mathrm{g})$, excess cold NGF $(2-4 \mu \mathrm{g})$, excess cold BDNF (2-4 $\mu \mathrm{g}), \mathrm{p} 75$ antibody $(10 \mu \mathrm{g})$, trkC antibody $(10 \mu \mathrm{g})$, normal $\mathrm{IgG}(10 \mu \mathrm{g}), \mathrm{K} 252 \mathrm{a}(1.8$ $\mu \mathrm{g})$, DMSO $(2 \mu \mathrm{l})$, wortmannin (200 ng, every $3 \mathrm{hr})$, LY294,002 (5 $\mu \mathrm{g})$, brefeldin A $(5-15 \mu \mathrm{g})$, and excess cold cytochrome $c(2-4 \mu \mathrm{g})$. Some of the embryos injected with ${ }^{125}$ I-NGF were coinjected with an equal amount of cold NT-3 (50-60 ng) or cold BDNF (50-60 ng).

Autoradiography and ultrastructural analysis. Autoradiography, localization, and quantification of ${ }^{125} \mathrm{I}$-neurotrophins was performed as de- scribed previously (von Bartheld et al., 1996a; von Bartheld, 2001). Embryos were anesthetized with Nembutal 3, 10, or $20 \mathrm{hr}$ after injection and intracardially perfused with $2.0 \%$ glutaraldehyde $/ 1 \%$ paraformaldehyde in PBS. Retinas were dissected and post-fixed in $2.5 \%$ glutaraldehyde $/ 0.5 \%$ paraformaldehyde in PBS, $\mathrm{pH} 7.4$, for $6 \mathrm{hr}$ at $4^{\circ} \mathrm{C}$, rinsed with PBS, and post-fixed in $1 \% \mathrm{OsO}_{4}$ for $2 \mathrm{hr}$ at room temperature. Retinas were dehydrated in graded alcohols to $100 \%$ ethanol, then washed with $100 \%$ propylene oxide and embedded in Spurr resin (Electron Microscopy Sciences, Fort Washington, PA). Thin sections on grids were coated with a monolayer of high-resolution Ilford L4 emulsion using the "loop method" (Caro and van Tubergen, 1962). After 1-2 months of exposure, the autoradiograms were developed in D19 (Kodak), fixed, and stained with $2.5 \%$ aqueous lead citrate. Sections were examined and photographed or scanned in a Philips CM 10 transmission electron microscope equipped with a Gatan 792 BioScan digital imaging system. RGCs and amacrine cells in the retinal ganglion cell layer were distinguished using established ultrastructural criteria (Prada et al., 1989).

To ensure adequate sampling of each retina, we sectioned blocks for each experiment from two to three different areas containing RGCs. Sections from each block were collected on several grids. The background level of silver grains was determined by photographing six to nine areas containing resin only (at a magnification of $4000-5000 \times$ ). Background levels were consistently negligible over individual grids. From each grid, two to three squares were analyzed. In each square, all RGCs with silver grains were photographed at a magnification of $11,000-$ $20,000 \times$. Autoradiography of sections through the optic tectum loaded with ${ }^{125}$ I-NT-3 by anterograde transport from the retina followed the protocol of von Bartheld et al. (1996a). In short, samples of the superficial tectum were embedded in Spurr's, thin-sectioned, coated with Ilford L4 emulsion, and exposed for 8-12 weeks for autoradiography. Grains over cell bodies in superficial layers were photographed and printed at 20,000-40,000 magnification, and the probable source was analyzed as described below. The fractional area of organelles from all labeled tectal cell bodies containing silver grains was measured as described below.

The circle probability method with a half-distance (HD) of $90 \mathrm{~nm}$ (Salpeter et al., 1978) was used to analyze and quantify the source of grains. The half-distance is the distance from a line source of radioactivity within which $50 \%$ of the grains are predicted to originate (Salpeter et al., 1978). Quantification was restricted to the RGC cell body; neurites and growth cones were not considered in this study, because correlation of neurite fragments with particular cell types is impossible without identifying labels. The average area occupied by particular organelles was determined by morphometric analysis (referred to as fraction area). Electron micrographs were overlaid with a transparent grid with a diameter of 1.5-2 $\mathrm{HD}$, and the frequency of organelles intersecting the grid was scored. To ascertain that treatment with K252a or DMSO did not change the organelle fraction area, treated retinas were compared with normal retinas; no differences were found.

The "labeling density" of organelles was determined by dividing the percentage of silver grains found over organelles by the percentage of the fraction area of that organelle. A labeling density of $\leq 1$ indicates that silver grains were distributed randomly, whereas a labeling density much more than 1 indicates a specific association of silver grains with this organelle. To determine at which threshold a labeling density demonstrates specific accumulation, all data were subjected to statistical analysis, using the distribution of free iodide and denatured NT-3 as controls. The total numbers of silver grains for each category (100-200) were assigned randomly to two to four groups, and both $t$ test and one-way ANOVA were used to determine whether labeling densities in the experimental groups were significantly $(p \leq 0.05)$ different from control groups (random distribution). This analysis revealed that all labeling densities of $>3.3$ were significant, whereas those $<2.4$ were not. It should be noted that such analyses depend on the number of silver grains analyzed, and the variability in both the control and the experimental groups, and thus will differ between studies.

Denaturation of NT-3. Previously radiolabeled NT-3 was incubated in $100 \mathrm{~mm}$ Tris- $\mathrm{HCl}, \mathrm{pH} 8.7$, and $50 \mathrm{~mm}$ dithiothreitol. The mixture was boiled for $5 \mathrm{~min}$ and cooled down to room temperature, and the generated free sulfhydryl groups were alkylated with iodoacetamide $(200 \mathrm{~mm})$. The preparation was reacted for $2 \mathrm{hr}$ at room temperature and then desalted by membrane filtration (Ultrafree MC filters, Millipore, Bedford, MA; $10 \mathrm{kDa}$ cutoff) using at least $25 \mathrm{vol}$ of sodium acetate buffer (10 mM sodium acetate, $100 \mathrm{~mm}$ sodium chloride, $\mathrm{pH} 4.0$ ). The incorporation and specific activity of the denatured ${ }^{125}$ I-NT-3 were determined by TCA precipitation. Thus denatured NT-3 does not bind to receptors 
in assays of internalization and anterograde transport (von Bartheld et al., 1996a).

Purification of retinal ganglion cells and internalization of NT-3. RGCs from E20 chick embryos were purified by using a simple immunopanning step with Thy1 antibodies (Butowt et al., 2000). This procedure yields $\sim 100,000-200,000$ RGCs per retina with a purity of $\sim 97 \%$. Retinas of E18-E21 chick embryos were pooled, and cell suspensions were divided equally onto $55 \mathrm{~mm}$ plates (in duplicate) for immunopanning. All plates were visually inspected on an inverted microscope containing a counting box, and the number of panned cells was estimated $(100,000-300,000$ cells per plate) to ensure that amounts of immunopanned cells were comparable. After immunopanning, cells were incubated for $3 \mathrm{hr}$ in $10-20 \mathrm{ng} / \mathrm{ml}{ }^{125} \mathrm{I}-\mathrm{NT}-3\left(1-2 \times 10^{6} \mathrm{cpm}\right.$ per plate $)$ in "binding buffer" (PBS, pH 7.4, containing $1 \mathrm{mg} / \mathrm{ml}$ bovine serum albumin and $1 \mathrm{mg} / \mathrm{ml}$ glucose) (Vale and Shooter, 1985), at either $4^{\circ} \mathrm{C}$ (control) or $37^{\circ} \mathrm{C}$. Duplicate plates at $37^{\circ} \mathrm{C}$ were incubated with either $1 \mu \mathrm{g} / \mathrm{ml}$ DMSO

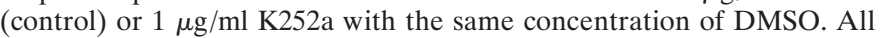
solutions of this and the subsequent steps were collected for gamma counting. After the $3 \mathrm{hr}$ incubation period at 4 or $37^{\circ} \mathrm{C}$, the binding buffer was removed, cells were washed with PBS and stripped with an ice-cold acid wash for $5 \mathrm{~min}$ (0.5 M NaCl, $0.2 \mathrm{M}$ acetic acid, pH 2.5) (Bernd and Greene, 1984). Again, it was verified by visual inspection on the inverted microscope that comparable amounts of cells were retained at this step. Cells were washed with PBS and then collected in single detergent lysis buffer (50 mm TrisCl, pH 7.6, $150 \mathrm{~mm} \mathrm{NaCl,} \mathrm{1 \%} \mathrm{Triton} \mathrm{X-100).} \mathrm{It} \mathrm{was}$ verified for each plate by inspection on the inverted scope that virtually all cells were removed from the plates. All solutions (incubation buffer, first wash buffer, acid wash, second wash buffer, lysis buffer) for each plate were counted separately in a gamma counter, and the percentage of internalization (counts in lysis buffer divided by counts in incubation buffer + counts in lysis buffer) was determined as well as the contribution of nonspecific association (counts in lysis buffer at $4^{\circ} \mathrm{C}$ divided by counts in incubation buffer at $4^{\circ} \mathrm{C}+$ counts in lysis buffer). The results from four independent experiments (each in duplicate) were subjected to unpaired $t$ test for statistical analysis. Because the large majority $(>80 \%)$ of NT-3 binding to RGCs was specific (i.e., was competed by 50 - to 100 -fold excess cold NT-3; data not shown), the binding seen at $37^{\circ} \mathrm{C}$ must be largely specific binding.

$S D S-P A G E$ gel electrophoresis. To determine whether the radioactivity contained within cells in the in vivo experiments represented intact neurotrophins or their breakdown products, 18 - to 20 -d-old chick embryos were injected in the eye with radiolabeled neurotrophins NGF, BDNF, or NT-3, and after $10 \mathrm{hr}$, RGCs were purified as described above. After intraocular injection of 50-100 ng radiolabeled NGF, BDNF, or NT-3, or free iodide as a control, retinas were collected $10 \mathrm{hr}$ later and pooled, and the cells were dissociated and immunopanned. Purified RGCs were used for analysis by SDS-PAGE or for lysis, cross-linking, and immunoprecipitation with neurotrophin receptor antibodies (see below). After immunopanning, purified RGCs or samples of whole retina (without immunopanning) were washed five times in PBS (containing $0.2 \% \mathrm{BSA}$ ), $\mathrm{pH} 7.4$, dissolved in $2 \times$ Laemmli electrophoresis sample buffer, homogenized by repetitive pipetting, and centrifuged at $10,000 \times g$ for $10 \mathrm{~min}$ at $4^{\circ} \mathrm{C}$. The supernatant was boiled for $5 \mathrm{~min}$ and centrifuged, and its radioactivity was determined by gamma counting. Between 1,000 and 10,000 cpm were loaded per lane on 15\% SDS-PAGE gels. Low molecular weight protein standard (Life Technologies, Gaithersburg, MD) or cytochrome $c$ was used as molecular weight indicators. Gels were stained with Coomassie blue, dried, and exposed to Kodak XR-5 x-ray film for 3-6 d. As a control for trypsin digestion of BDNF during the dissociation procedure, trypsin-digested BDNF was examined on SDS-PAGE.

Neurotrophin receptor in situ hybridization. A chicken p75 cDNA, subcloned into pGEM4Z, was used to generate riboprobes (436 bp fragment) labeled with ${ }^{35}$ S-UTP (Heuer et al., 1990). Animals of E15/16 were anesthetized and perfused with $4 \%$ PFA. The eyes were either frozen for cryosectioning $(10 \mu \mathrm{m})$ and thaw mounted onto poly-L-lysinecoated slides or dehydrated, embedded in paraffin, and sectioned at 10 $\mu \mathrm{m}$, and sections through the central retinas were collected on silanecoated glass slides. Adjacent sections were hybridized with sense control probes. Hybridization conditions were as described previously (von Bartheld et al., 1991). Emulsion (NTB-2)-coated paraffin sections were exposed for 14-28 d, developed, and lightly counterstained with thionin. Chicken $\operatorname{trk} \mathrm{A}$, trkB, and $\operatorname{trkC}$ oligonucleotide probes recognizing the kinase domain (von Bartheld et al., 1996b) were hybridized to cryosections from E16 and E18 retinas, coated in NTB-2 emulsion, and devel- oped after 4-6 weeks. These sections were lightly counterstained with cresyl violet. The autoradiographic label of cells in the central ganglion cell layer (GCL) was quantified in both series of slides by using a reticule in the eye piece. The level of background grains was measured in adjacent sense control sections, and the values were subtracted to normalize for specific label intensities.

Cross-linking and immunoprecipitation. Chick embryos at the age of 16-18 d of incubation (E16-18) were injected with 20-40 ng radiolabeled NT-3 in the eye in ovo. Twenty hours later, the animals were anesthetized with Nembutal and transcardially perfused with cold PBS. The retina, the optic chiasm, and the contralateral optic tectum were dissected and collected in cold PBS, chopped into small pieces, and homogenized in lysis buffer using 22 gauge needles. For analysis of internalized neurotrophins in RGC bodies, immunopanning was used for purification (Butowt et al., 2000). RGCs were lysed after immunopanning, and $2-10 \%$ of RGCs $(1000-5000 \mathrm{cpm})$ were recovered. Lysis buffer consisted of $50 \mathrm{~mm}$ TrisCl (pH 6.5 for EDC, pH 7.6 for DSS), $150 \mathrm{~mm}$ $\mathrm{NaCl}, 100 \mu \mathrm{g} / \mathrm{ml}$ aprotinin, $1 \%$ Triton $\mathrm{X}-100,1 \mu \mathrm{g} / \mathrm{ml}$ leupeptin, and 0.5 $\mathrm{mm}$ PMSF. One of two cross-linkers was added to the homogenates for $30 \mathrm{~min}$ at room temperature in a rotating device (nutator): EDC (Pierce Chemical, Rockford, IL) at $6 \mathrm{~mm}, \mathrm{pH} 6.5$, or DSS (Pierce) at $0.1 \mathrm{~mm}, \mathrm{pH}$ 7.6. The cross-linking reaction was terminated by incubation in cold PBS containing $50 \mathrm{~mm}$ lysine for $30 \mathrm{~min}$. The preparation was centrif uged for 5-10 min at $4^{\circ} \mathrm{C}$, and pellets and supernatants were counted separately in a gamma counter. Usually $70-80 \%$ of the total counts were retained in the supernatant. The supernatant was incubated overnight at $4^{\circ} \mathrm{C}$ with 1.4-1.7 $\mu \mathrm{g} / \mathrm{ml}$ polyclonal antibodies against chick $\mathrm{p} 75$, trkB, or trkC, or the same concentration of normal rabbit $\mathrm{IgG}$ as control. The next day, 10-20 $\mu$ l of washed Pansorbin cells (Calbiochem, La Jolla, CA) were added to the preparation for $1 \mathrm{hr}$ in the cold room, the immunocomplex was pelleted by centrifugation for $5 \mathrm{~min}$ in the cold room, and the pellets and supernatants were counted separately in a gamma counter. All determinations were done in triplicate. Nonspecific precipitation was subtracted by using the counts from the control (IgG-incubated) pellets. We are using the terminology of "specific precipitation" to indicate that the antibodies were presumably precipitating their antigens specifically, but not to indicate that the binding of the neurotrophin was "specific" (i.e., competed by excess cold = receptor bound). Nevertheless, it can be assumed that the antibody precipitates only those neurotrophins that are bound to receptors, thus presumably precipitating indeed only specifically bound neurotrophins. Control experiments included (1) incubation of normal lysed tissues with similar amounts of radiolabeled NT-3 to assess whether free NT-3 may bind to different receptors when they become available during lysis, (2) omission of the cross-linking step, and (3) repeated immunoprecipitation of the same supernatants to determine the efficiency with which the antibodies pulled down the receptors. Statistical significance was determined by unpaired $t$ test.

\section{RESULTS}

\section{Anterograde transport of NT-3 is receptor-mediated}

We have shown previously that the anterograde axonal transport of exogenous NT-3 in RGCs is receptor mediated (von Bartheld et al., 1996a). To determine which receptors mediate the internalization and anterograde transport of NT-3, excess amounts of cold homologous factor were coinjected. Background radioactivity (attributable to systemic circulation) was assessed by coinjection of the Golgi-blocking agent monensin (Hammerschlag et al., 1982). Excess cold NT-3 (20- to 200-fold) significantly reduced transport of radiolabeled NT-3 (Fig. $1 A$ ). To test the contribution of the p75 neurotrophin receptor for NT-3 transport, excess cold NGF (20- to 100-fold) was coinjected. This would also examine trkA binding of NT-3, but trkA is not expressed in chick RGCs (Karlsson et al., 1998). To test the contribution of p75 and trkB receptors for NT-3 internalization, excess cold BDNF (50- to 100 -fold) was coinjected. Coinjection of heterologous neurotrophins that should prevent the binding of NT-3 to the p75 receptor (NGF) or the trkB receptor (BDNF) (DiStefano et al., 1992; Rodriguez-Tebar et al., 1992) did not reduce the internalization or the anterograde transport of NT-3 (Fig. 1A). Coinjection of blocking antibodies against p75 at doses that significantly reduce 

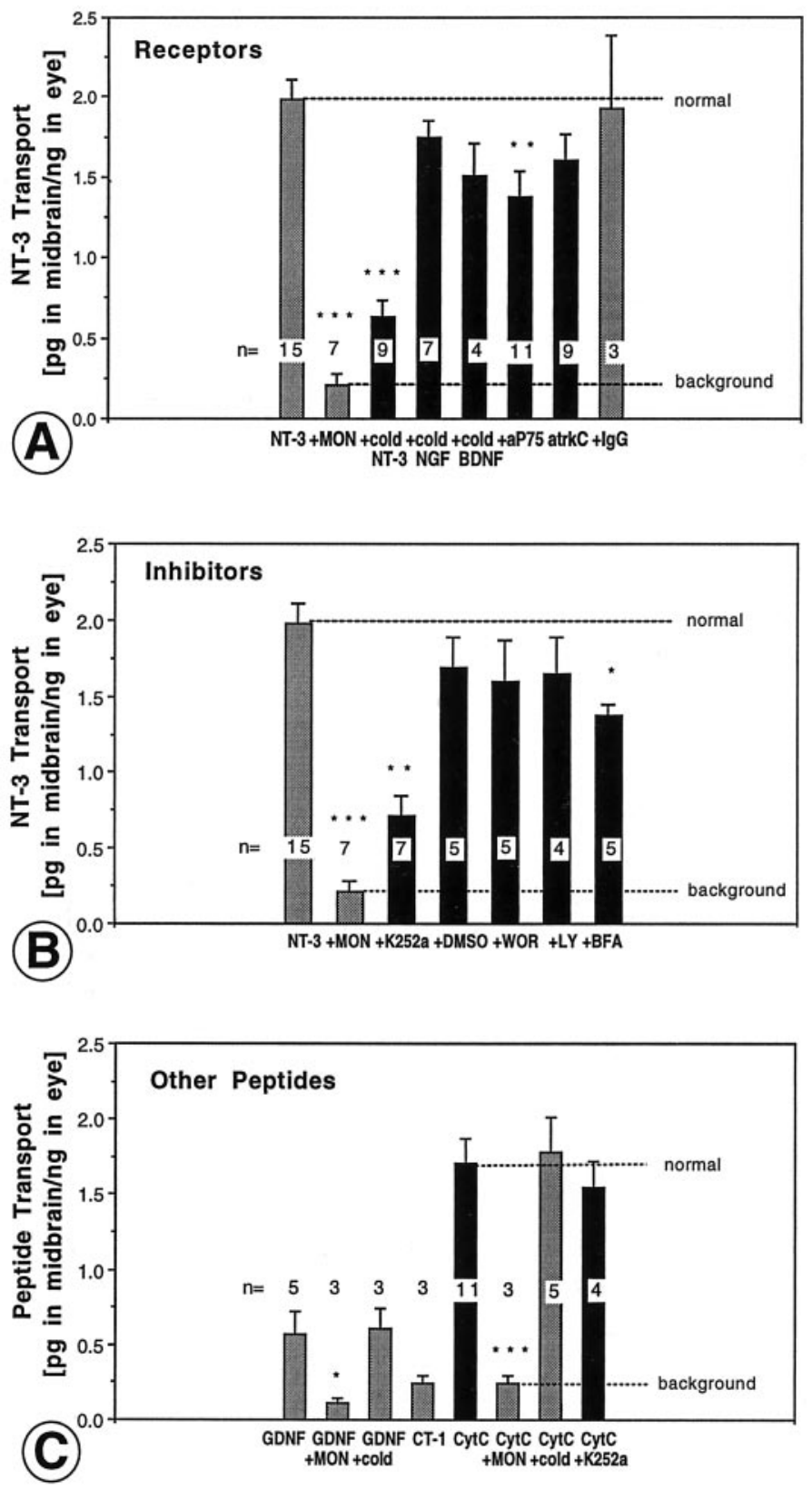

Figure 1. $A-C$, Anterograde axonal transport of neurotrophic factors and cytochrome $c$ in chick RGCs. $A, B$, The relative amount of anterograde transport of radiolabeled NT-3 was plotted by dividing the amount measured by gamma counting in the tectum (counts per minute per specific activity in picograms) by the amount measured in the eye (counts per minute per specific activity in nanograms) at the time chick embryos were killed ( $20 \mathrm{hr}$ after injection in the eye). $A$, The effects of coinjection of monensin (MON) (von Bartheld et al., 1996a), excess cold NT-3 (cold $N T-3$ ), excess cold NGF (cold NGF), or excess cold BDNF (cold BDNF), blocking p75 antibody ( $($ P 75), blocking trkC antibody (atrkC), and normal rabbit $\operatorname{IgG}(\operatorname{IgG}) . B$, The effects of coinjection of monensin $(M O N)$, tyrosine kinase inhibitor K252a (K252a), vehicle (DMSO), wortmannin (WOR), LY294,002 (LY), and brefeldin A (BFA) (von Bartheld et al., 1996a) are indicated. $C$, The relative amount of anterograde transport of radiolabeled glial cell line-derived neurotrophic factor (GDNF), cardiotrophin-1 (CT1), and cytochrome $c(C y t C)$ was plotted by dividing the amount measured by gamma counting in the midbrain (picograms) by the amount measured in the eye (nanograms) at the time chick embryos were killed (20 hr after injection in the eye). The effects of coinjection of monensin (MON), excess cold GDNF, or CytC, and K252a are indicated. Error bars indicate SEM. The number of independent experiments is indicated. ${ }^{* * *} p \leq 0.005 ;{ }^{* *} p \leq 0.01 ;{ }^{*} p \leq 0.05$. retrograde axonal transport of NT-3 (von Bartheld et al., 1996b) only slightly reduced anterograde NT-3 transport. Together, these data indicate that neither the p75 receptor nor the trkB receptor is required for internalization of NT-3 by RGCs. To directly test whether trkC is essential for internalization, we sought to use a trkC antibody that had been shown to interfere with trkC signaling (Lefcort et al., 1996). However, at the doses used (10 $\mu \mathrm{g}$ per eye), there was no effect on the anterograde transport of NT-3 by RGCs (Fig. $1 A$ ). Normal IgG was used as a control for these experiments (Fig. $1 A$ ). Because it has not been established that this trkC antibody can prevent the binding of NT-3 to the trkC receptor (as opposed to inhibiting trkC function by allosteric interactions) (Taniuchi and Johnson, 1985; Bothwell, 1995), these data, collectively, are consistent with the notion that RGCs internalize NT-3 primarily via trkC receptors rather than $\mathrm{p} 75$.

\section{Anterograde transport requires tyrosine kinase but not PI3-kinase activity}

To determine whether tyrosine kinase activity may play a role in the anterograde transport of NT-3, as reported previously for the sorting of other receptor ligands (Felder et al., 1990; Bos et al., 1993; Opresko et al., 1995; Mukherjee et al., 1997), radiolabeled NT-3 was coinjected with K252a, a relatively specific tyrosine kinase inhibitor (Knusel and Hefti, 1992). K252a does not reduce internalization of NGF (Kahle et al., 1994) or BDNF (von Bartheld et al., 1996b), yet this compound (1.8 $\mu \mathrm{g}$ per eye) dramatically reduced anterograde transport of NT-3 (Fig. 1B). Because $\mathrm{K} 252 \mathrm{a}$ has to be dissolved in DMSO, control embryos received intraocular injections of similar amounts $(2 \mu \mathrm{l})$ of DMSO with the radiolabeled NT-3. DMSO alone had no significant effect on the NT-3 transport. The PI3-kinase inhibitors wortmannin and LY294,002 have been implicated in protein trafficking and NGF internalization (Vlahos et al., 1994; Bartlett et al., 1997; Gallo and Letourneau, 1998; Shitara et al., 1998; Mallet and Maxfield, 1999; York et al., 2000). Therefore, we tested whether coinjection of these compounds with NT-3 affected anterograde transport. Neither wortmannin (200 ng; single or three times repeated doses over $10 \mathrm{hr}$ ) nor LY294,002 $(0.5 \mu \mathrm{l}$ of $100 \mu \mathrm{M})$ had an effect on anterograde transport of internalized NT-3 (Fig. 1B). This is surprising, because internalization of NGF via trkA in PC12 cells is substantially reduced by PI3-kinase inhibitors (York et al., 2000), but the data may be explained by differences between neurotrophins, between in vivo/in vitro approaches, or the time course examined (minutes vs hours). The inhibitor of endoplasmic reticulum (ER)-to-Golgi traffic, brefeldin A, has been implicated in transcytosis of receptor ligands in some cell types but not in others (Hunziker et al., 1991; Lippincott-Schwartz et al., 1991). Brefeldin A (5-15 $\mu \mathrm{g})$ slightly, but significantly, reduced NT-3 transport (Fig. $1 B$ ), indicating that this drug does not dramatically impair endosome trafficking required for NT-3 anterograde transport. We conclude that the activity of tyrosine kinase, but not PI3-kinase, has a significant role in the internalization, sorting, and targeting of NT-3.

\section{Cytochrome $c$ as a control for nonspecific anterograde transport}

To determine whether other proteins with similar size and charge as neurotrophins can be anterogradely transported, radiolabeled GDNF, CT-1, and cytochrome $c$ were injected into the eye of chick embryos. Anterograde transport of GDNF was relatively sparse, and although it was blocked by monensin, it could not be 


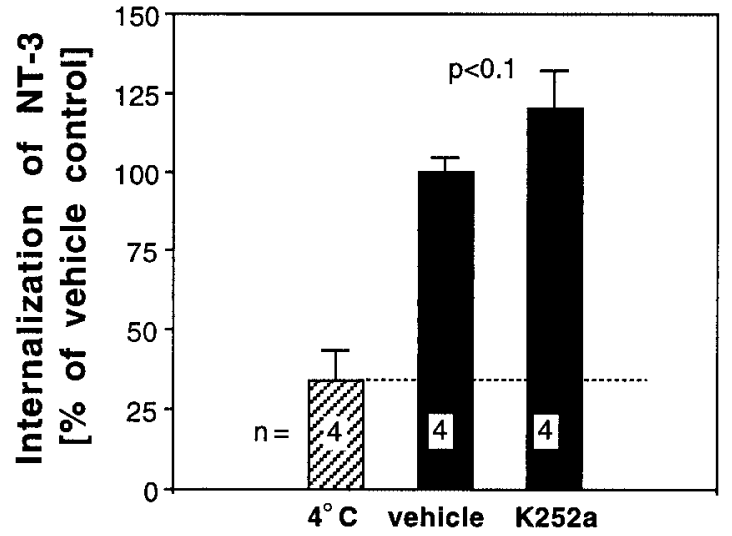

Figure 2. Internalization of ${ }^{125} \mathrm{I}-\mathrm{NT}-3(10-20 \mathrm{ng} / \mathrm{ml})$ in purified retinal ganglion cells from E18-21 chick embryos does not require tyrosine kinase activity. The amount of internalization in the presence of $1 \mu \mathrm{g} / \mathrm{ml}$ $\mathrm{K} 252 \mathrm{a}$ (tyrosine kinase inhibitor) is plotted as the percentage relative to the values for vehicle (1 $\mu \mathrm{g} / \mathrm{ml}$ DMSO), which were averaged to $100 \%$ internalization ( $\sim 40,000 \mathrm{cpm}$ per plate). Nonspecific association of NT-3 $\left(\right.$ at $4^{\circ} \mathrm{C}$ ) is indicated (dotted line). Error bars indicate SEM. The number of independent experiments (each in duplicate) is indicated. The $p$ level for confidence ( $t$ test) is indicated, showing no significant effect of K252a on NT-3 internalization.

blocked with excess cold GDNF and thus was not receptor mediated (Fig. 1C). Anterograde transport of CT-1 was even less and barely measurable (Fig. $1 C$ ). By contrast, significant amounts of cytochrome $c$ were transported to the tectum, with an efficiency only slightly less than NT-3 (Fig. $1 C$ ). The transport of cytochrome $c$ was blocked almost entirely by monensin, but the cytochrome $c$ transport could not be reduced with excess cold cytochrome $c$ (Fig. 1C), indicating that its transport was not receptor mediated. To determine whether K252a generally reduces axonal transport, or whether K252a has specific effects on transport of NT-3 (Fig. $1 B$ ), radiolabeled cytochrome $c$ was coinjected with K252a. The anterograde transport of cytochrome $c$ was not diminished by K252a (Fig. 1C), showing that blockade of trk tyrosine kinase activity does not reduce axonal transport in general, but rather has a specific effect on internalization, sorting, or axonal transport of NT-3.

\section{Internalization of NT-3 does not require tyrosine kinase activity}

Because anterograde axonal transport of exogenous NT-3 requires internalization and sorting, as well as axonal transport, K252a could affect either of these steps or more than one step. It has been shown that neither NGF (Kahle et al., 1994) nor BDNF (von Bartheld et al., 1996b) requires tyrosine kinase activity for internalization, but it is not known whether this holds for NT-3 as well. To determine whether internalization of NT-3 is diminished in $\mathrm{K} 252 \mathrm{a}$-treated cells and thus to more precisely localize the effect of K252a on anterograde transport, we tested whether NT-3 internalization is reduced in K252a-treated purified RGCs. Internalization of $10-20 \mathrm{ng} / \mathrm{ml}{ }^{125} \mathrm{I}-\mathrm{NT}-3$ was not diminished by treatment with $1 \mu \mathrm{g} / \mathrm{ml} \mathrm{K252a}$ (Fig. 2), a dose that reliably blocks tyrosine kinases including trk receptors (Knusel and Hefti, 1992). Approximately two-thirds of the NT-3 in the RGCs was specific internalization, as shown by control experiments at $4^{\circ} \mathrm{C}$ that prevent neurotrophin internalization but not binding (Vale and Shooter, 1985) and by cold competition experiments which showed that $>80 \%$ of NT-3 binding to RGCs is specific (data not shown). Because it could be argued that internalization of neu- rotrophins in vitro and in cells purified by a step that involves trypsinization may alter the receptor makeup at the cell surface membranes, we verified that NT-3 internalization in vivo does not require tyrosine kinase activity by using the isthmo-optic nucleus as a model system as in previous studies (von Bartheld et al., 1996b). When ${ }^{125}$ I-NT-3 was coinjected with K252a in the eye, the retrograde axonal transport of ${ }^{125} \mathrm{I}-\mathrm{NT}-3$ from the eye to the isthmo-optic nucleus was not significantly diminished (data not shown), indicating that tyrosine kinase activity is not required for internalization at axon terminals and retrograde axonal transport of NT-3 in vivo. Taken together, these data confirm that none of the neurotrophins so far investigated (NGF, BDNF, or NT-3) require tyrosine kinase activity for internalization. In a broader perspective, these data add to the list of trophic receptor functions that do not require tyrosine kinase activity (Kullander et al., 2001). Furthermore, our data show that the effect of K252a on anterograde axonal transport of exogenous NT-3 involves a step subsequent to internalization that is likely a sorting step (see below).

\section{Relative expression levels of p75, trkB, and trkC in the GCL}

Cells in the GCL of chick embryos express p75 mRNA (von Bartheld et al., 1991; Karlsson et al., 1998). Chick GCL cells also express trkB and trkC (Garner et al., 1996; Hallböök et al., 1996; Das et al., 1997), but unlike mammalian RGCs (von Bartheld, 1998a), chick RGCs do not express trkA at the protein or mRNA level (Karlsson et al., 1998). The relative contributions of RGCs and amacrine cells to expression levels of neurotrophin receptors are not known. To semiquantitatively compare levels of expression of p75, trkB, and trkC in RGCs, E18 retinas were hybridized with neurotrophin receptor probes, and autoradiographic grains were counted over cells in sections from the central regions of the retina, where the large majority of cells comprise RGCs (Ehrlich, 1981). Probes for p75, kinase-specific trkB, or kinase-specific trkC were used, and background grains (measured in adjacent control sections hybridized with sense probes) were subtracted. With this analysis, approximately twice the amount of trkB than trkC or p75 mRNA was seen in presumptive RGCs (Fig. 3). Because most cells in the central GCL are RGCs, but with the caveat that message levels do not always reflect protein levels, we conclude that RGCs probably express significantly larger amounts of trkB than trkC or p75 at this age (E18).

\section{Ultrastructural distribution of NT-3 in RGCs: comparison with NGF and BDNF}

On the basis of the apparent expression of p75, trkB, and trkC receptors by many RGCs, one would expect that RGCs may internalize NGF (via p75), BDNF (via p75 or trkB), and NT-3 (via $\mathrm{p} 75$, trkB, or trkC). Thus, binding to different receptors may determine intracellular pathways. To examine whether different members of the neurotrophin family accumulate in the same or in different organelles within RGC cell bodies, radiolabeled neurotrophins were injected into the vitreous body in E18-19 embryos, and after $10 \mathrm{hr}$ the tissues were processed to quantify the distribution of autoradiographic grains at the ultrastructural level.

For the identification of RGCs within the GCL (which contains RGCs as well as amacrine cells), we used the fact that RGCs differ considerably from amacrine cells at the ultrastructural level (Prada et al., 1989; H. Kolb, personal communication). RGCs have a much more extensive and characteristic rough ER as compared with amacrine cells (Fig. 4). For the following analysis, 
Figure 3. $A-D$, In situ hybridization for neurotrophin receptors in the central region of the ganglion cell layer $(G C L)$ of 16- to 18-d-old chick embryos. This area contains $\sim 85-90 \%$ retinal ganglion cells (Ehrlich, 1981). A, Cells labeled for p75 neurotrophin receptor mRNA. $B$, Cells labeled with probes specific for the tyrosine kinase domain of the chick trkB neurotrophin receptor. $C$, Cells labeled with probes specific for the tyrosine kinase domain of the chick trkC receptor. Scale bars, $5 \mu \mathrm{m}$. $D$, The intensity of labeling (Grains/Cell) is plotted against the relative frequency (percentage of cells with this labeling intensity). Note that trkB-labeled cells contain nearly twice the number of grains as p75- or trkC-labeled cells (after subtraction of background). The number of cells sampled is indicated.
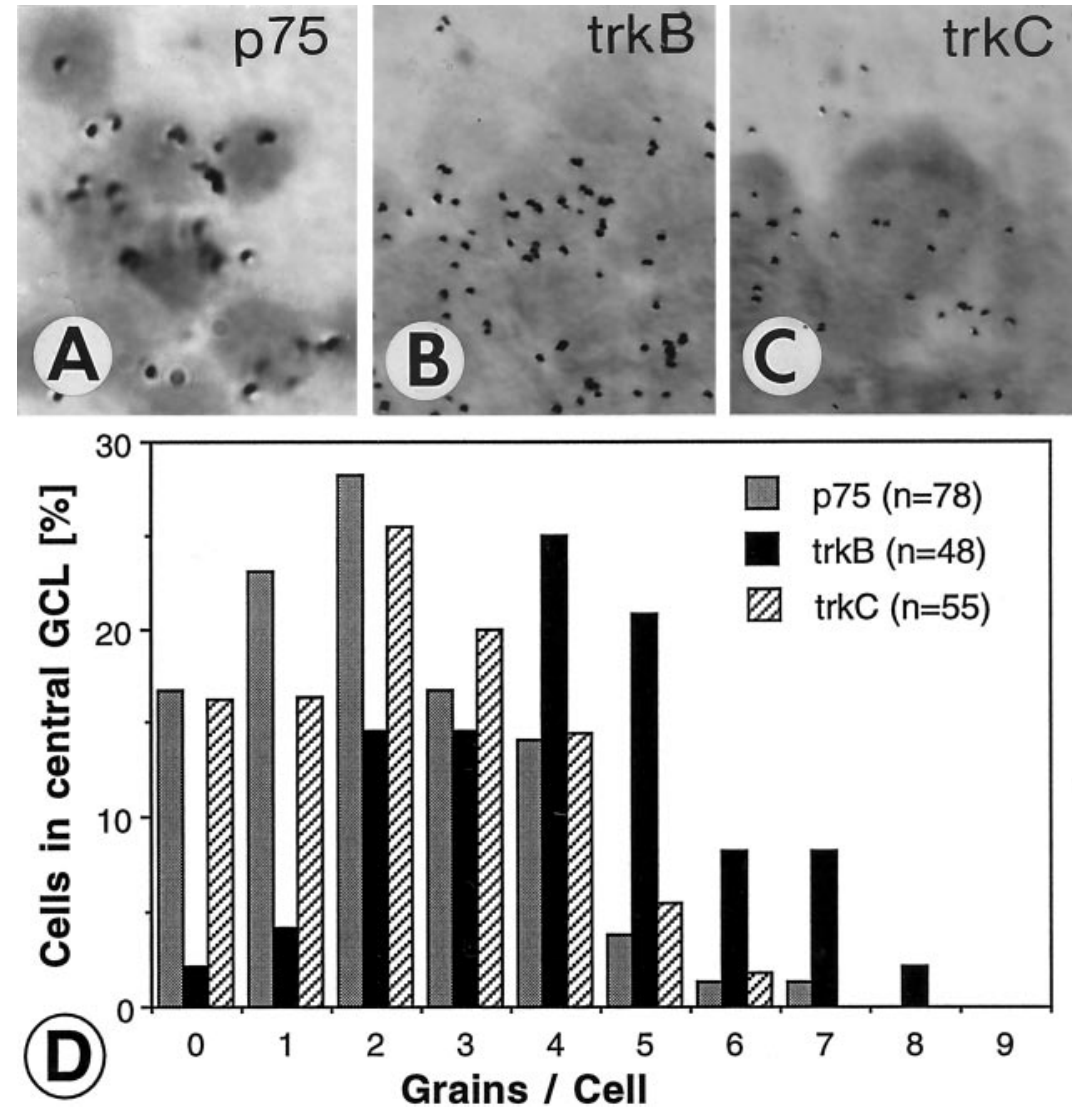

only those RGCs that could be unambiguously identified and distinguished from amacrine cells were used.

For the quantitative analysis of grain accumulation in RGCs, a half-distance analysis of source probability (Salpeter et al., 1978) was applied to a total of $\sim 1700$ silver grains from $\sim 650$ micrographs printed at 20,000-40,000× magnification, with at least 100 grains from two to three retinas analyzed for each treatment group. Examples of silver grains over five different types of organelles in RGCs are shown in Figure $5 A-E$. For control purposes (to verify that the grains truly represent the respective neurotrophins), embryos were injected into the vitreous with similar amounts of denatured radiolabeled NT-3 or with free iodine. There was no preferential accumulation of grains over particular organelles in these control experiments (i.e., silver grains precisely reflected the fractional area of each organelle), consistent with a random background distribution (Table 1). The distribution of denatured NT-3 and free iodine matched the percentiles of fractional areas; accordingly, their labeling density (LD $=\%$ grains $/ \%$ fractional area) was $\sim 1.0$ or less (Table 1 ). LDs of $>3.3$ were statistically significant in our material, whereas LDs of $<2.4$ were not significantly different from control groups.

The most striking differences in distribution between the neurotrophins were the accumulation of $\mathrm{NGF}$ and BDNF, but not NT-3, at the plasma membrane (Table 1), the accumulation of $\mathrm{BDNF}>\mathrm{NT}-3>\mathrm{NGF}$ in multivesicular bodies (MVBs) (Table 1 ), and the accumulation of NT-3 (and, to a lesser extent, of BDNF) in the Golgi apparatus (including those vesicles that were clearly Golgi-associated) (Fig. 5E, Table 1). Nearly $20 \%$ of the internalized NT-3 in RGC somata was located within the Golgi system. The Golgi passage of internalized NT-3 is novel, because it has not been described previously for trophic factors internal- ized in neurons. The lack of NGF in the Golgi system is consistent with previous studies on internalized NGF (see Discussion). Also, the accumulation of all neurotrophins in endosomes (including lysosomes) is consistent with previous reports. In our analysis, we did not attempt to distinguish between light endosomes, dark endosomes, and lysosomes, because these categories have ill-defined criteria (Nixon and Cataldo, 1995; Mukherjee et al., 1997), resulting in significant variability between investigators. None of the experimental or control groups showed label in the nucleus or in the nuclear membrane; therefore, these two categories were combined in Tables 1-4. Twenty percent of the NT-3 silver grains were found over the Golgi system, and the same percentage was previously estimated to be transported to the optic tectum (von Bartheld et al., 1996a). We conclude that $\sim 20 \%$ of the NT-3 within RGCs follows the Golgi and potential anterograde transport pathway. We calculate that on average each RGC contained 1000-2000 NT-3 dimers and transported $20 \%=200-$ 400 NT-3 dimers to the tectum. Collectively, these data show that neurotrophins have different patterns of accumulation, probably reflecting different intracellular pathways of internalized receptor-ligand complexes.

\section{Time course of NGF, BDNF, and NT-3 accumulation: 3, 10, and $20 \mathrm{hr}$}

Because the $10 \mathrm{hr}$ time point after internalization presents only a snapshot of the distribution and does not reveal kinetics of processing, the $10 \mathrm{hr}$ time point was compared with an early ( $3 \mathrm{hr}$ ) and a late $(20 \mathrm{hr})$ time point after injection of the radiolabeled neurotrophins NGF, BDNF, and NT-3 in the eye. NGF accumulated $3 \mathrm{hr}$ after injection in the plasma membrane, with a subsequent decrease of labeling in the plasma membrane and an 


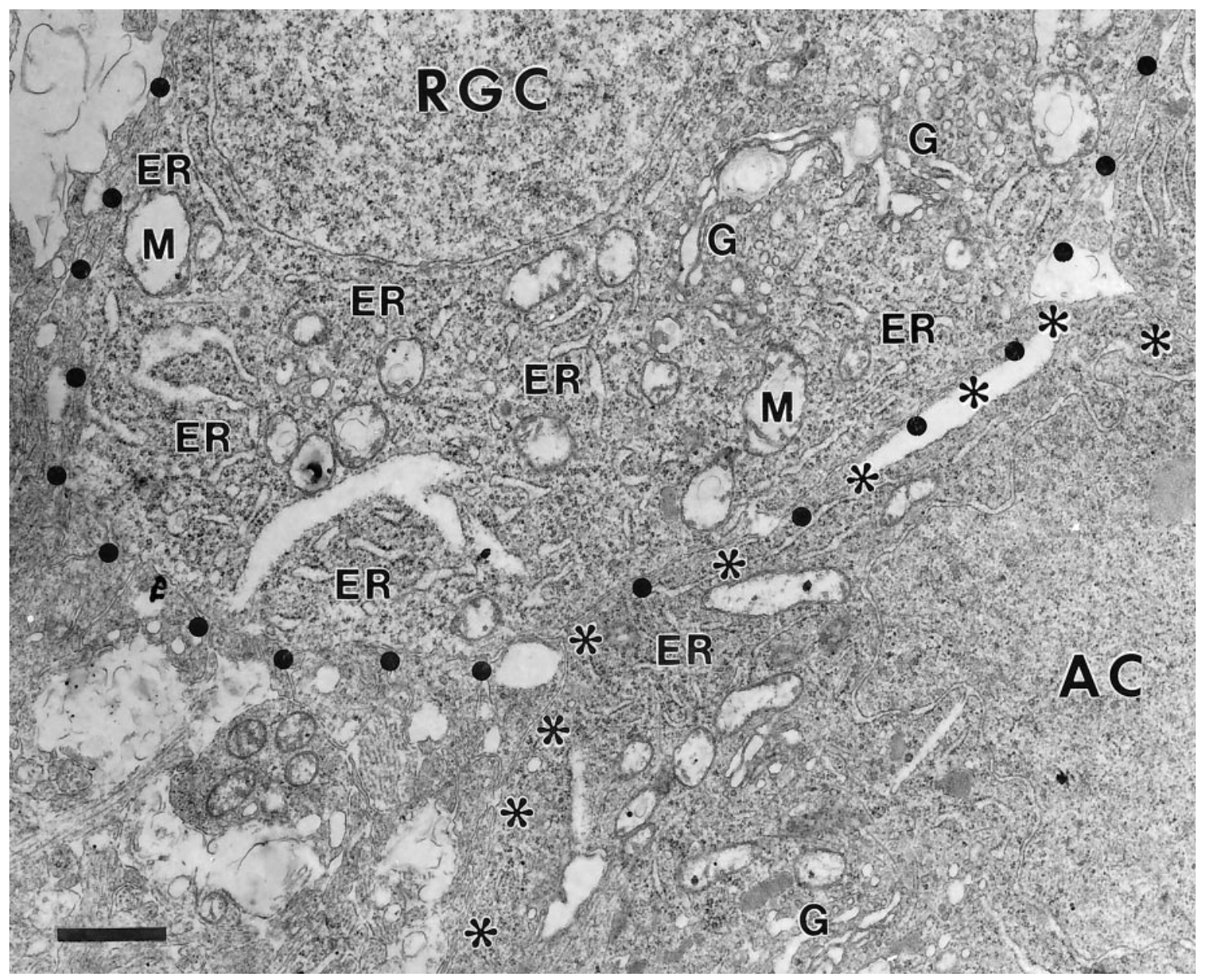

Figure 4. Ultrastructure of a retinal ganglion cell $(R G C)$ and an amacrine cell $(A C)$ in the ganglion cell layer of an 18-d-old chick embryo. The plasma membrane of the RGC is marked by black dots; the plasma membrane of the AC is marked with asterisks. Note the abundance of rough endoplasmic reticulum $(E R)$ in the RGC, and the paucity of such organelles in the AC. $G$, Golgi system; $M$, mitochondrion. This retina was injected with NT-3 and processed after $10 \mathrm{hr}$. Scale bar, $1 \mu \mathrm{m}$.

increased targeting to endosomes and lysosomes. Much of the BDNF was found 3 and $10 \mathrm{hr}$ after injection at the plasma membrane, then it accumulated at $10-20 \mathrm{hr}$ in the ER and endosomes (Table 2). NT-3 was strikingly absent from the plasma membrane at all time points examined (3, 10, and $20 \mathrm{hr}$ ), but accumulated at 3 and $10 \mathrm{hr}$ in the Golgi system, and at 10-20 hr in MVBs and endosomes/lysosomes, whereas NT-3 decreased in the Golgi system at $20 \mathrm{hr}$ (Table 2). These dynamic patterns of distribution confirm the hypothesis that different neurotrophins follow different intracellular pathways after internalization in RGCs, especially for the plasma membrane and the Golgi system.

\section{Effect of K252a on the distribution of BDNF and NT-3 in RGCs}

Tyrosine kinase activity has been implicated in sorting of internalized receptor-ligand complexes (Felder et al., 1990; Bos et al., 1993; Opresko et al., 1995). Because coinjection of K252a (but not DMSO vehicle alone) substantially reduced the anterograde transport of exogenous NT-3 (Fig. $1 B$ ), but not its internalization (Fig. 2), we tested the hypothesis that blockade of trk activity may alter the pattern of NT-3 accumulation and specifically that K252a may reduce the accumulation of NT-3 in the Golgi system, which is known to be required for anterograde axonal transport of newly synthesized proteins (Hammerschlag et al., 1982).
Coinjection of K252a significantly altered the pattern of accumulation of BDNF and NT-3 in RGCs after 10 hr. The accumulation of NT-3 and BDNF in the Golgi apparatus was abolished. The labeling densities dropped from 4.56 to 0.76 (NT-3) and 2.39 to 0.51 (BDNF) (Fig. 6 $A$, Table 3 ), whereas the accumulation of BDNF and NT-3 in endosomes and lysosomes was much increased (Fig. 6B; Table 3). In addition to the effect on the endosomes and lysosomes, K252a also increased the labeling density of NT-3 at the plasma membrane, making the NT-3 pattern more similar to that seen with NGF and BDNF (compare Tables 1 and 3 ). Other patterns of distribution were not much altered, with the exception of a decrease of the BDNF labeling density for MVBs (reduction from 6.8 to 1.5). These data confirm that tyrosine kinase activity (presumably trkC activity) sorts NT-3 into the Golgi-anterograde pathway, whereas its absence directs the neurotrophins into the degradative lysosomal pathway or increases their retention at, or recycling to, the plasma membrane.

\section{Comparison with accumulation after axo-dendritic transfer in tectum}

Different cell types may traffic internalized neurotrophins into different compartments. To determine subcellular routes of internalized NT-3 in neurons other than RGCs, we examined the 

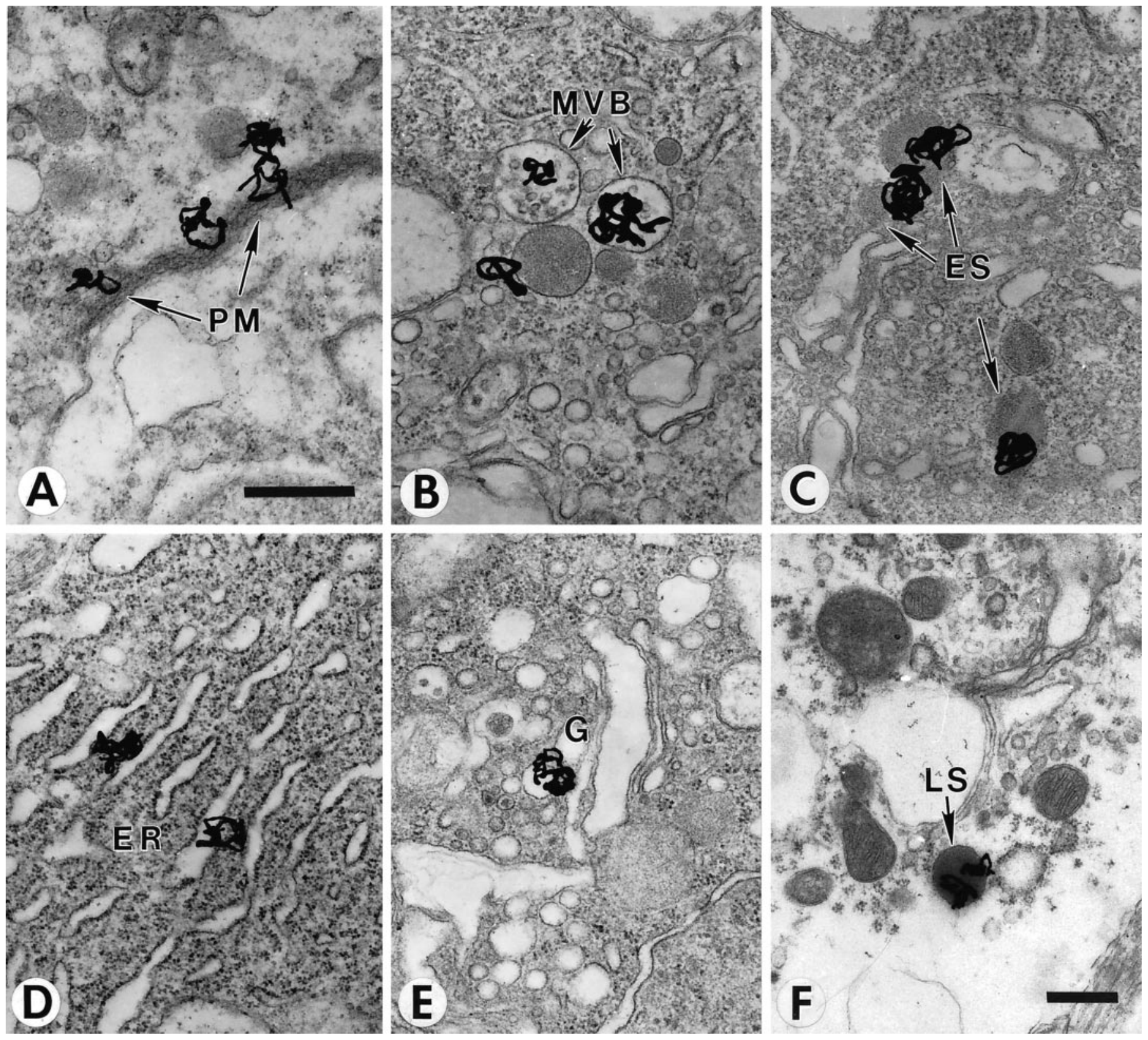

Figure 5. $A-F$, Examples of accumulation of radiolabeled internalized neurotrophins over organelles in E18 retinal ganglion cells $(A-E)$ and tectal cells $(F) . A$, Accumulation at the plasma membrane $(P M)$; BDNF after $10 \mathrm{hr}$. Three silver grains touch the PM. $B$, Accumulation in multivesicular bodies $(M V B)$; NT-3 after $20 \mathrm{hr}$. C, Accumulation in dense endosomes $(E S)$; NT-3 after $10 \mathrm{hr} . D$, Accumulation in the endoplasmic reticulum (ER); NT-3 after $20 \mathrm{hr}$. E, Accumulation in the Golgi apparatus $(G)$ and Golgi-associated vesicles; NT-3 after $10 \mathrm{hr}$. F, Accumulation in a lysosome $(L S)$; NT-3 after 20 $\mathrm{hr}$ and anterograde transport in RGC axons and axo-dendritic transfer to a tectal cell in a 16-d-old chick embryo. Scale bars (shown in $A$ for $A-D$ ), 500 $\mathrm{nm}$; (shown in $F$ for $E, F$ ), $500 \mathrm{~nm}$.

pattern of accumulation of NT-3 after axo-dendritic transfer from RGC axons and internalization into tectal neurons. ${ }^{125}$ I-NT-3 was injected into the eye, and $20 \mathrm{hr}$ later samples of the contralateral tectum were processed for autoradiography. When silver grains over neuronal cell bodies in the tectum were analyzed, NT-3 was found to be similarly concentrated over MVBs and lyso/endosomes as in RGCs (Tables 1, 4), but NT-3 did not accumulate in the Golgi system of tectal neurons (Table 4). It is not known whether these neurons anterogradely transport internalized NT-3. Nevertheless, these data indicate that there are differences between cell types in the trafficking of the same neurotrophin.

\section{NT-3 directs NGF into the anterograde pathway}

If our hypothesis is correct that trkC activity enhances the sorting of internalized NT-3 into the anterograde axonal pathway, then one would predict that coinjection of a small amount of NT-3 (to activate trkC) with NGF (which binds to p75, but not trkC) may facilitate the anterograde transport of NGF, provided that they are internalized into the same vesicle or endosome. A positive result would also indicate that the membranes of the internalized vesicles contain both types of receptors, trkC as well as p75. To test this hypothesis, 50-100 ng radiolabeled NGF was coinjected with 50-60 ng cold NT-3, or 50-60 ng cold BDNF as a negative 
Table 1. Distribution of autoradiographic silver grains and labeling densities in organelles of retinal ganglion cells $10 \mathrm{hr}$ after intraocular injection in chick embryos

\begin{tabular}{|c|c|c|c|c|c|c|c|c|c|c|c|}
\hline \multirow[b]{2}{*}{ Organelle } & \multicolumn{2}{|l|}{ NGF } & \multicolumn{2}{|c|}{$\mathrm{BDNF}$} & \multicolumn{2}{|l|}{ NT-3 } & \multicolumn{2}{|c|}{$\begin{array}{l}\text { Denatured } \\
\text { NT-3 }\end{array}$} & \multicolumn{2}{|c|}{ Free ${ }^{125} \mathrm{I}$} & \multirow[b]{2}{*}{ Fractional area $(\%)$} \\
\hline & $\%$ & LD & $\%$ & $\mathrm{LD}$ & $\%$ & LD & $\%$ & LD & $\%$ & LD & \\
\hline Plasma membrane & 25.1 & 4.65 & 20.0 & 3.70 & 6.7 & 1.24 & 5.2 & 0.96 & 6.9 & 1.28 & 5.4 \\
\hline Vesicles & 6.2 & 1.05 & 9.9 & 1.68 & 9.8 & 1.66 & 5.4 & 0.91 & 5.3 & 0.90 & 5.9 \\
\hline Cytoplasm & 14.1 & 0.77 & 13.7 & 0.74 & 20.2 & 1.10 & 18.3 & 0.99 & 20.3 & 1.10 & 18.4 \\
\hline MVB & 2.2 & 2.20 & 6.8 & 6.80 & 5.5 & 5.50 & 2.0 & 2.00 & 0.7 & 0.70 & 1.0 \\
\hline Lyso/endosome & 11.9 & 7.93 & 7.7 & 5.13 & 11.6 & 7.73 & 2.6 & 1.73 & 3.4 & 2.27 & 1.5 \\
\hline Golgi & 4.7 & 1.15 & 9.8 & 2.39 & 18.7 & 4.56 & 3.6 & 0.88 & 4.1 & 1.00 & 4.1 \\
\hline ER & 15.1 & 1.23 & 14.4 & 1.17 & 10.1 & 0.82 & 9.9 & 0.80 & 12.6 & 1.02 & 12.3 \\
\hline Nucleus/membrane & 11.6 & 0.30 & 8.4 & 0.22 & 4.2 & 0.11 & 43.7 & 1.14 & 32.7 & 0.85 & 38.4 \\
\hline Mitochondria & 3.0 & 0.39 & 2.0 & 0.26 & 4.6 & 0.60 & 4.0 & 0.53 & 5.2 & 0.68 & 7.6 \\
\hline Unidentified & 6.1 & 1.15 & 7.2 & 1.36 & 8.6 & 1.62 & 5.4 & 1.02 & 8.6 & 1.62 & 5.3 \\
\hline$n$ & 106 & & 162 & & 119 & & 50 & & 58 & & 363 \\
\hline
\end{tabular}

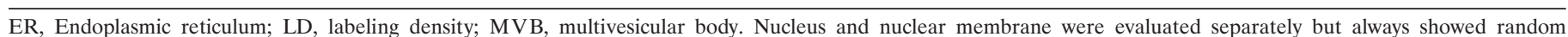
distribution and were grouped together. LDs of $>3.3$ (statistical significance at $p \leq 0.05$ ) are indicated in bold.

Table 2. Distribution of autoradiographic silver grains representing NGF, BDNF, and NT-3 and their labeling densities in organelles of retinal ganglion cells 3, 10, and $20 \mathrm{hr}$ after intraocular injection in chick embryos

\begin{tabular}{|c|c|c|c|c|c|c|c|c|c|c|c|c|c|c|c|c|c|c|}
\hline \multirow[b]{3}{*}{ Organelle } & \multicolumn{6}{|l|}{ NGF } & \multicolumn{6}{|c|}{ BDNF } & \multicolumn{6}{|l|}{ NT-3 } \\
\hline & \multicolumn{2}{|l|}{$3 \mathrm{hr}$} & \multicolumn{2}{|l|}{$10 \mathrm{hr}$} & \multicolumn{2}{|l|}{$20 \mathrm{hr}$} & \multicolumn{2}{|l|}{$3 \mathrm{hr}$} & \multicolumn{2}{|l|}{$10 \mathrm{hr}$} & \multicolumn{2}{|l|}{$20 \mathrm{hr}$} & \multicolumn{2}{|l|}{$3 \mathrm{hr}$} & \multicolumn{2}{|l|}{$10 \mathrm{hr}$} & \multicolumn{2}{|l|}{$20 \mathrm{hr}$} \\
\hline & $\%$ & LD & $\%$ & LD & $\%$ & $\mathrm{LD}$ & $\%$ & LD & $\%$ & LD & $\%$ & $\mathrm{LD}$ & $\%$ & $\mathrm{LD}$ & $\%$ & $\mathrm{LD}$ & $\%$ & $\mathrm{LD}$ \\
\hline Plasma membrane & 31.3 & 5.8 & 25.1 & 4.65 & 19.6 & 3.63 & 18.2 & 3.37 & 20.0 & 3.70 & 9.0 & 1.67 & 7.5 & 1.39 & 6.7 & 1.24 & 3.7 & 0.69 \\
\hline Vesicles & 8.2 & 1.39 & 6.2 & 1.05 & 10.2 & 1.73 & 13.4 & 2.27 & 9.9 & 1.68 & 10.8 & 1.83 & 8.8 & 1.49 & 9.8 & 1.66 & 13.4 & 2.27 \\
\hline Cytoplasm & 18.7 & 1.02 & 14.1 & 0.77 & 26.6 & 1.45 & 18.1 & 0.98 & 13.7 & 0.74 & 7.8 & 0.42 & 29.2 & 1.59 & 20.2 & 1.10 & 10.9 & 0.59 \\
\hline MVB & 0.6 & 0.60 & 2.2 & 2.20 & 1.8 & 1.80 & 5.8 & 5.80 & 6.8 & 6.80 & 6.3 & 6.30 & 5.7 & 5.70 & 5.5 & 5.50 & 6.6 & 6.60 \\
\hline Lyso/endosome & 10.2 & 6.80 & 11.9 & 7.93 & 12.7 & 8.47 & 2.5 & 1.67 & 7.7 & 5.13 & 14.1 & 9.40 & 10.2 & 6.80 & 11.6 & 7.73 & 15.1 & 10.07 \\
\hline Golgi & 3.3 & 0.80 & 4.7 & 1.15 & 3.0 & 0.73 & 6.5 & 1.58 & 9.8 & 2.39 & 8.8 & 2.15 & 13.4 & 3.27 & 18.7 & 4.56 & 5.8 & 1.41 \\
\hline ER & 9.0 & 0.80 & 15.1 & 1.23 & 4.9 & 0.40 & 16.6 & 1.35 & 14.4 & 1.17 & 24.2 & 1.97 & 8.6 & 0.70 & 10.1 & 0.82 & 23.3 & 1.89 \\
\hline Nucleus/membrane & 10.5 & 0.27 & 11.6 & 0.30 & 14.3 & 0.37 & 8.3 & 0.22 & 8.4 & 0.22 & 6.3 & 0.16 & 1.9 & 0.05 & 4.2 & 0.11 & 6.6 & 0.17 \\
\hline Mitochondria & 2.0 & 0.26 & 3.0 & 0.39 & 1.8 & 0.24 & 3.6 & 0.47 & 2.0 & 0.26 & 4.8 & 0.63 & 2.5 & 0.33 & 4.6 & 0.61 & 4.6 & 0.61 \\
\hline Unidentified & 6.7 & 1.26 & 6.1 & 1.15 & 5.1 & 0.96 & 7.2 & 1.36 & 7.2 & 1.36 & 7.5 & 1.42 & 9.0 & 1.70 & 8.6 & 1.62 & 8.0 & 1.51 \\
\hline$n$ & 171 & & 106 & & 112 & & 132 & & 162 & & 120 & & 108 & & 119 & & 188 & \\
\hline
\end{tabular}

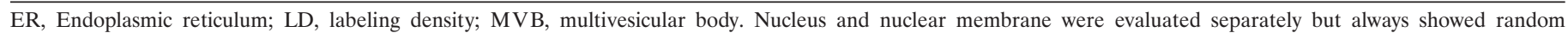
distribution and were grouped together. LDs of $>3.3$ are indicated in bold.

control, into the eye of 15- to 16-d-old chick embryos, and the amount of anterogradely transported NGF relative to the amount retained in the eye at the time embryos were killed was calculated. Consistent with our prediction, coinjection of cold NT-3 increased the anterograde transport of radiolabeled NGF significantly, by over $27 \%$, whereas coinjection of cold BDNF had no effect (Fig. 6C). These data support the notion that activated trkC, but not activated trkB, directs the internalized neurotrophin-receptor complex into an anterograde transport pathway. These data also indicate that a significant fraction of neurotrophins are internalized in, or at least transiently merge with, vesicles with membranes that contain both p75 and trkC receptors.

\section{Cleavage and degradation of internalized neurotrophins in purified RGCs}

Rapid degradation of internalized neurotrophins has been reported for NGF in sympathetic neurons, sensory ganglion cells, enteric cells, and PC12 cells (Johnson et al., 1978; Siminoski et al., 1986; Eveleth and Bradshaw, 1992; Ure and Campenot, 1997), but not for BDNF internalized in cultured astrocytes and Schwann cells (Rubio, 1997; Alderson et al., 2000), and relatively slow "clipping" of transcytosing bFGF (Ferguson et al., 1990). Compared with control experiments using free iodine and denatured NT-3, internalized intact NT-3 distributes differently and thus likely represents ligand that still can bind to its receptor. Autoradiography of tissue sections, however, does not assess the extent of possible degradation after internalization. To determine the extent to which internalized neurotrophins are degraded in RGCs, RGCs were purified 10-12 hr after intraocular injection of radiolabeled neurotrophins, and the recovered radioactive samples were subjected to either TCA precipitation or SDSPAGE analysis. Because we know the yield of immunopanned RGCs ( 100,000-200,000 per retina at this age) and the amount of radioactivity and the specific activity of radiolabeled NT-3, we can calculate that on average, each RGC internalized $\sim 0.1 \mathrm{fg}=$ 2000 dimers NT-3 in the cell body (excluding dendrites/axons, 

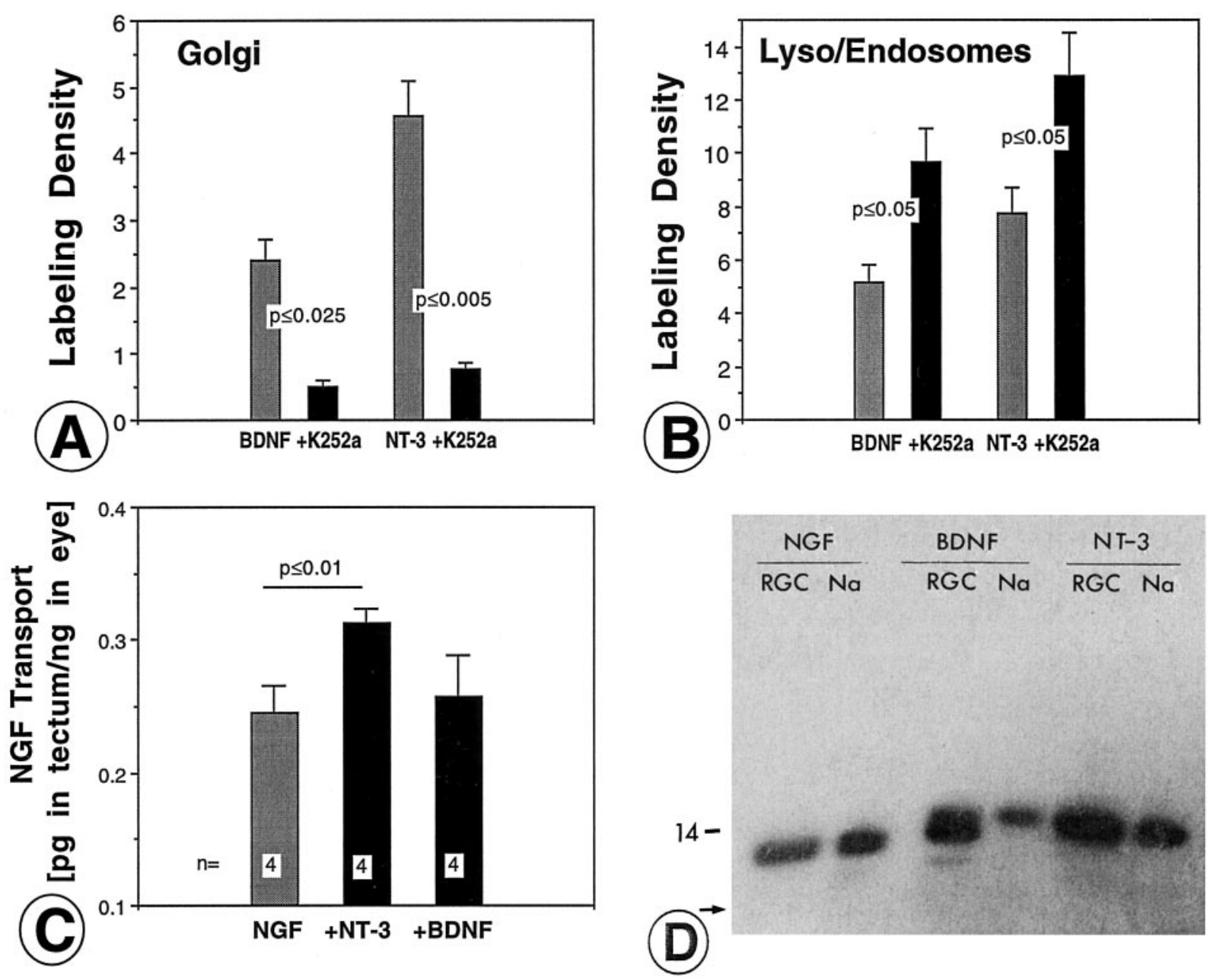

Figure 6. $A-D$, Effect of $\mathrm{K} 252 \mathrm{a}$ and trkC activity on the distribution of internalized neurotrophins in retinal ganglion cells $(R G C)(A-C)$ and SDS-PAGE analysis of internalized neurotrophins in purified RGCs $(D)$. A , Labeling densities of internalized BDNF and NT-3 in the Golgi system of RGCs with and without K252a. The analysis was done in triplicate; significance was determined by unpaired $t$ test. $B$, Labeling densities of internalized BDNF and NT-3 in lysosomes and endosomes of RGCs with and without K252a. The analysis was done in triplicate; significance was determined by unpaired $t$ test. $C$, Quantification of anterograde transport of 50-80 ng radiolabeled NGF when coinjected in the eye with 50-60 ng cold NT-3 or BDNF. The number of experiments is indicated. Significance was determined by unpaired $t$ test. Error bars indicate SEM. D, SDS-PAGE (15\%) of internalized neurotrophins NGF, BDNF, and NT-3 recovered from purified immunopanned RGCs after $10 \mathrm{hr}$. Each sample was run with an adjacent sample of native same factor $(\mathrm{Na})$. The molecular weight is indicated. Arrow indicates the dye front. Note that much of the BDNF recovered from RGCs is cleaved, whereas virtually all the NGF and NT-3 is intact protein by this analysis.

and possibly excluding surface binding that may have been removed by the extensive washes). TCA precipitation showed that incorporation was unchanged compared with the native radiolabeled neurotrophin (data not shown), indicating that very little, if any, ligand was degraded into free iodine, or that such iodine was rapidly released from the RGCs. When the lysed cell extracts of purified RGC somata were analyzed on $15 \%$ SDS-PAGE, the NGF and NT-3 migrated as bands that were indistinguishable from the native radiolabeled protein, whereas BDNF showed multiple bands, with a major band at $\sim 10 \mathrm{kDa}$, a minor band at $14 \mathrm{kDa}$, and a faint band close to the dye front at $\sim 3-5 \mathrm{kDa}$ (Fig. $6 D$ ), where small degradation products (but not necessarily free iodide) can be expected. Cleavage was not apparent when ${ }^{125} \mathrm{I}-$ BDNF was recovered from whole retinal extracts, but only when RGCs were purified, and the same pattern of cleavage was seen when native BDNF was incubated with trypsin (data not shown). One possible explanation for differences in neurotrophin degradation is that a major fraction of the BDNF internalized in RGCs was exposed to trypsin during the 10 min digestion for dissocia- tion. Such data may point to a rapid recycling of BDNF (and its receptor, presumably trkB) between endosomes and the surface membrane. This cleavage does not seem to render the major BDNF fragment functionally impaired [consistent with previous reports for NGF (Mercanti et al., 1977) and bFGF (Ferguson et al., 1990)], because ${ }^{125}$ I-BDNF cleaved with trypsin was axonally transported in a retrograde transport assay (data not shown). These results indicate that major fractions of each of the three neurotrophins may be differentially processed after internalization in RGCs, presumably by targeting into different compartments or intracellular pathways, so that NGF is predominantly targeted to lysosomes, BDNF is recycled to the surface membrane, and NT-3 is targeted to the Golgi-anterograde pathway.

\section{Cross-linking and immunoprecipitation of internalized neurotrophins in purified RGCs: internalization of NT-3 via trkC receptors}

Because many different cell types in the retina express neurotrophin receptors (von Bartheld, 1998a), neurotrophins may bind to 
Table 3. Distribution of autoradiographic silver grains and labeling densities in organelles of retinal ganglion cells $10 \mathrm{hr}$ after intraocular injection of BDNF or NT-3 in chick embryos with or without the tyrosine kinase inhibitor K252a

\begin{tabular}{|c|c|c|c|c|c|c|c|c|}
\hline \multirow[b]{2}{*}{ Organelle } & \multicolumn{2}{|c|}{ BDNF } & \multicolumn{2}{|c|}{$+\mathrm{K} 252 \mathrm{a}$} & \multicolumn{2}{|l|}{ NT-3 } & \multicolumn{2}{|c|}{$+\mathrm{K} 252 \mathrm{a}$} \\
\hline & $\%$ & LD & $\%$ & $\mathrm{LD}$ & $\%$ & $\mathrm{LD}$ & $\%$ & $\mathrm{LD}$ \\
\hline Plasma membrane & 20.0 & 3.70 & 19.8 & 3.67 & 6.7 & 1.24 & 19.0 & 3.52 \\
\hline Vesicles & 9.9 & 1.68 & 12.0 & 2.03 & 9.8 & 1.66 & 6.6 & 1.12 \\
\hline Cytoplasm & 13.7 & 0.74 & 17.7 & 0.96 & 20.2 & 1.10 & 13.4 & 0.73 \\
\hline MVB & 6.8 & 6.80 & 1.5 & 1.50 & 3.5 & 3.50 & 3.6 & 3.60 \\
\hline Lyso/endosome & 7.7 & 5.13 & 14.5 & 9.67 & 11.6 & 7.73 & 19.4 & 12.9 \\
\hline Golgi & 9.8 & 2.39 & 2.1 & 0.51 & 18.7 & 4.56 & 3.1 & 0.76 \\
\hline ER & 14.4 & 1.17 & 12.2 & 0.99 & 10.1 & 0.82 & 16.9 & 1.37 \\
\hline Nucleus/membrane & 8.4 & 0.22 & 10.3 & 0.27 & 4.2 & 0.11 & 10.6 & 0.28 \\
\hline Mitochondria & 2.0 & 0.26 & 3.7 & 4.9 & 4.6 & 0.60 & 4.3 & 0.57 \\
\hline Unidentified & 7.2 & 1.36 & 6.7 & 1.26 & 8.6 & 1.62 & 3.0 & 0.57 \\
\hline$n$ & 162 & & 197 & & 119 & & 166 & \\
\hline
\end{tabular}

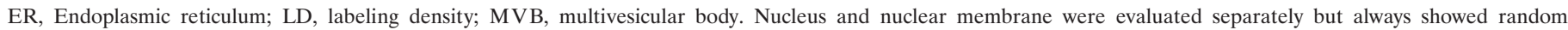
distribution and were grouped together. LDs of $>3.3$ are indicated in bold.

\begin{tabular}{|c|c|c|c|}
\hline Organelle & $\%$ & LD & Fractional area $(\%)$ \\
\hline Plasma membrane & 18.9 & 4.02 & 4.7 \\
\hline Vesicles & 4.7 & 0.85 & 5.5 \\
\hline Cytoplasm & 23.1 & 0.99 & 23.3 \\
\hline MVB & 2.7 & 27.00 & 0.1 \\
\hline Lyso/endosome & 12.1 & 7.12 & 1.7 \\
\hline Golgi & 0.0 & 0.00 & 4.2 \\
\hline ER & 8.0 & 0.54 & 14.7 \\
\hline Nucleus/membrane & 15.6 & 0.39 & 39.6 \\
\hline Mitochondria & 2.7 & 0.57 & 4.7 \\
\hline Unidentified & 7.8 & 4.59 & 1.7 \\
\hline$n$ & 90 & & 361 \\
\hline
\end{tabular}

ER, Endoplasmic reticulum; LD, labeling density; MVB, multivesicular body.

many different cell types after injection in the eye. To determine which receptors bind radiolabeled neurotrophins after intraocular injections specifically in RGCs, we purified RGCs, and then cross-linked the neurotrophins with EDC or DSS and immunoprecipitated with antibodies specific for chicken $\mathrm{p} 75$, chicken trkA, chicken trkB, or chicken trkC (Weskamp and Reichardt, 1991; von Bartheld et al., 1996b; Lefcort et al., 1996). These antibodies are thought to have roughly similar precipitation efficiencies (Herzog and von Bartheld, 1998) and allow a tentative qualitative comparison of receptor binding. Normal $\mathrm{IgG}$ was included in each experiment to determine nonspecific precipitation, which was subtracted from each data set to calculate specific precipitation. Data obtained with this technique have to be interpreted with caution and allow one to make conclusions only about relative changes in receptor association, rather than absolute levels of receptor binding, because the efficiencies of cross-linking and immunoprecipitation may vary. Nonspecific precipitation, generally $\sim 1-6 \%$, was subtracted from the total to calculate specific precipitation. Typically, the total amount precipitated by receptor-specific antibodies (after subtraction of nonspecific precipitation) was $12-30 \%$ of the total amount of radiolabeled neurotrophins in the preparation.
At $12 \mathrm{hr}$ after injection, internalized BDNF bound to trkB and p75 receptors with a ratio of $\sim 1: 1$, whereas NT-3 bound trkC almost exclusively with a ratio of 12:1 (trkC/p75) (Fig. 7C). There was no specific precipitation of BDNF or NT-3 with trkA antibodies, indicating that BDNF and NT-3 did not bind to trkA (data not shown). The lack of binding of NT-3 to p75 does not appear to be attributable to technical reasons, because the p75 antibody immunoprecipitated much of the receptor-bound BDNF ( 40\%) (Fig. $7 C$ ), and some NGF was precipitated with p75 antibodies (data not shown). There was no significant difference between the two cross-linkers used, EDC and DSS. The binding of NT-3 to the trkC receptor in RGCs was transient, because its precipitation was much reduced at $44 \mathrm{hr}$ after injection compared with $12 \mathrm{hr}$ after injection (Fig. $7 C$ ). The data do not allow us to rule out that NT-3 may bind p75 receptors at the cell surface, but if it does, the NT-3 does not seem to be internalized by this receptor type. We conclude that trkC, rather than $\mathrm{p} 75$ or trkB, binds NT-3 during the initial internalization and sorting steps within RGCs, consistent with the lack of effects of either excess cold NGF or BDNF competition or p75 blocking antibody in the coinjection experiments described above.

\section{Cross-linking and immunoprecipitation of NT-3 during anterograde transport: roles of trkC and p75}

To determine whether NT-3 remains bound to trkC during anterograde axonal transport and after arrival in the optic tectum, we dissected the retina, optic chiasm, and contralateral optic tectum $20 \mathrm{hr}$ after injection of the radiolabeled NT-3 in the eye, cross-linked with either EDC or DSS, and immunoprecipitated with chick p75, trkB, or trkC antibodies. Because it can be assumed that cross-linking and precipitation efficiencies do not change between preparations from retina, chiasm, and tectum for the same neurotrophin, this analysis should reveal major potential changes in the ratios of receptor binding. Therefore, the data are presented as percentages of the ratios of receptor binding, with the total binding to trkB, trkC, and $\mathrm{p} 75$ combined $=100 \%$ (Fig. $7 A, B)$.

The cross-linking and immunoprecipitation experiments revealed that, in the retina, $\sim 60 \%$ of immunoprecipitated NT-3 bound to $\mathrm{p} 75$, and $\sim 35 \%$ to trkC (data not shown). The difference compared with the purified RGC cell bodies is likely attributable to the substantial binding of neurotrophins in the inner 

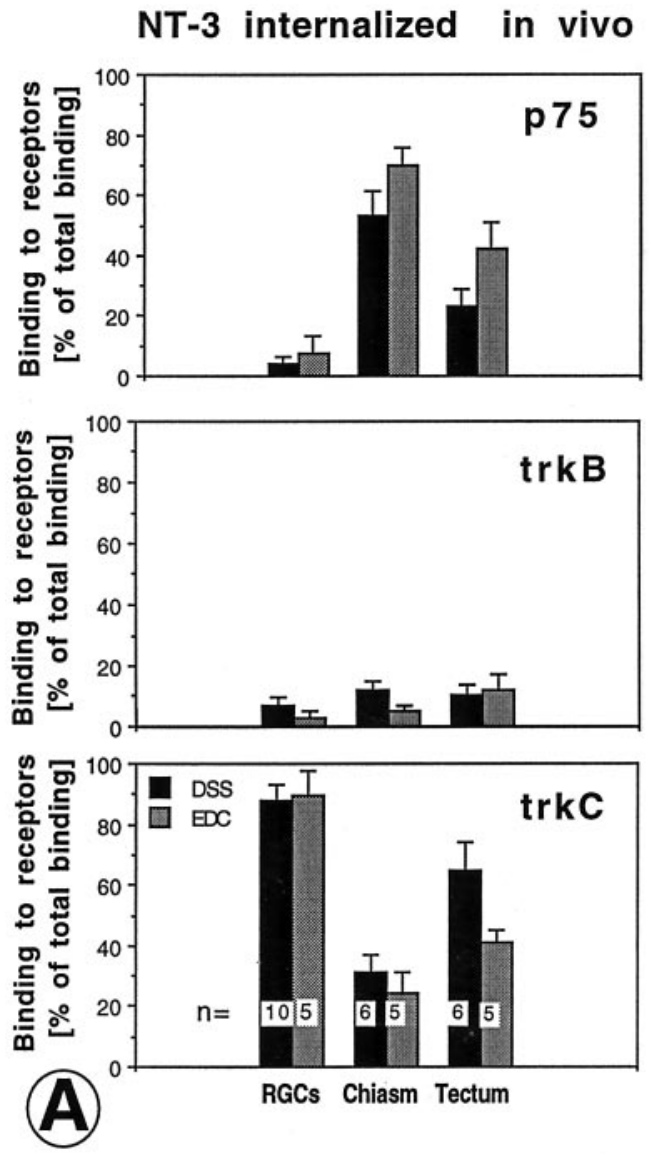
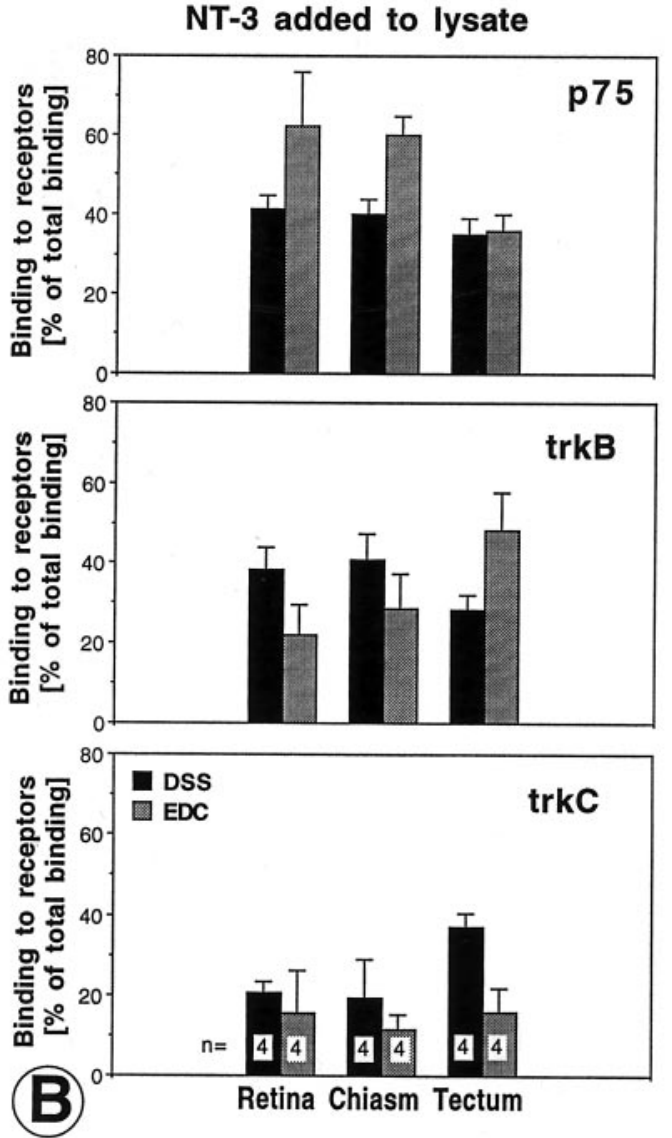

Control

Experiments: RGCs
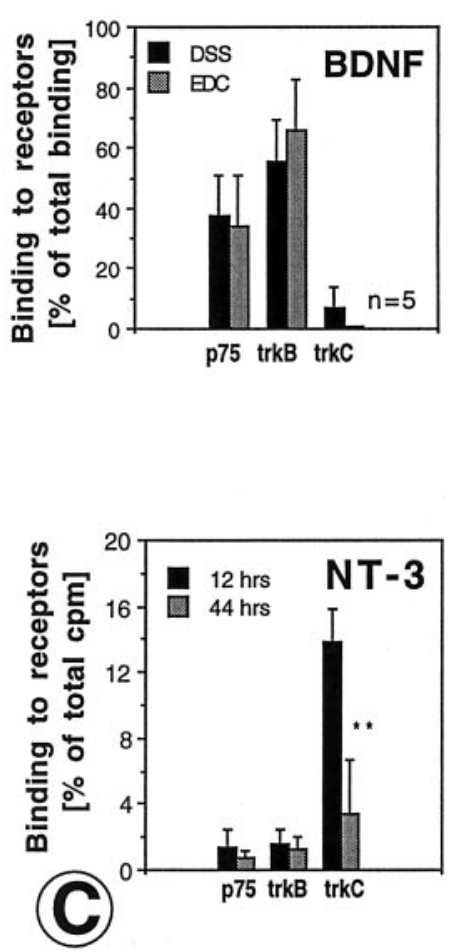

Figure 7. $A-C$, Cross-linking and immunoprecipitation of radiolabeled neurotrophins internalized and anterogradely transported by retinal ganglion cells $(R G C s)$. A, Binding of NT-3 to p75, trkB, and trkC receptors cross-linked with EDC or DSS and immunoprecipitated with chicken-specific neurotrophin receptor antibodies. The relative amount of total specific precipitation (after subtraction of nonspecific precipitation) is shown separately for each tissue (purified RGCs, optic chiasm, and optic tectum) and for each receptor. Totals for p75, trkB, and trkC (from top to bottom) add up to 100\% for each tissue and cross-linker. $B$, Binding of NT-3 to receptors when radiolabeled NT-3 was added to the same tissues and then cross-linked and immunoprecipitated. Note the much more extensive precipitation with trkB antibodies (binding to trkB) when NT-3 was added to normal lysates of the same tissues rather than introduction of NT-3 in vivo. $C$, Immunoprecipitation of internalized radiolabeled BDNF and NT-3 binding to receptors in RGCs purified by immunopanning. Note that BDNF binds to p75 as well as trkB, whereas NT-3 binds almost exclusively to trkC receptors at 12 hr; binding of NT-3 to trkC in RGCs is transient, because it is much reduced $44 \mathrm{hr}$ after injection $(C)$. Error bars indicate SEM. The number of experiments is indicated.

plexiform layer, which contains mostly neuropil. Here, p75 binding appears to predominate, consistent with the distribution of this receptor by immunolabeling (Das et al., 1997; Herzog and von Bartheld, 1998). In the optic chiasm, a significant fraction $(60 \%)$ bound to p75 and less $(25 \%)$ to trkC, but in the tectum the ratio between $\mathrm{p} 75(\sim 30 \%)$ and trkC $(50-60 \%)$ shifted back in favor of trkC (Fig. $7 A$ ). The percentages for cross-linking with either EDC or DSS were very similar, with DSS showing slightly higher ratios for the trk receptor, and EDC showing slightly higher ratios for the p75 receptor. This is in keeping with the known higher efficiencies of cross-linking for DSS (trks) and EDC (p75) (Escandon et al., 1993). Taken together, these data are consistent with the notion that NT-3 is internalized by trkC, then dissociates from trkC and gains access to $\mathrm{p} 75$, presumably as a "transporter" in RGC fibers within the optic nerve and tract (von Bartheld and Butowt, 2000). After arrival in the tectum, the p75-bound NT-3 is released and presumably binds to trkC on postsynaptic tectal target neurons (von Bartheld et al., 1996a). P75 has previously been identified as a trkB-ligandspecific retrograde transporter in projection neurons (Curtis et al., 1995).

\section{Control experiments for cross-linking and immunoprecipitation}

Control experiments were performed to verify that neurotrophins do not massively dissociate from their receptors and bind to other, previously not occupied, receptors that become available in the lysis step. When NT-3 was added to the untreated retina, chiasm, or tectum, the ratios of binding were significantly different. Notably, added NT-3 bound much more to trkB than it did when it was introduced into the RGC axons by intraocular injection, internalization, and anterograde axonal transport (Fig. 7B), indicating that many trkB receptors are present in fibers within the optic nerve that are unoccupied. When the cross-linking step was omitted, much neurotrophin binding to p75 was lost, whereas binding to trk receptors was maintained (data not shown), consistent with the notion that $\mathrm{p} 75$ receptors are "fast" receptors that bind ligands with a fast rate of dissociation, whereas trk receptors are thought to bind ligands with high affinity and release the neurotrophins slowly (Barker and Murphy, 1992; Bothwell, 1995). Because NT-3 also binds to isthmo-optic terminals and is transported retrogradely in the optic nerve (von Bartheld et al., 1996b), it was necessary to rule out a significant contribution of 


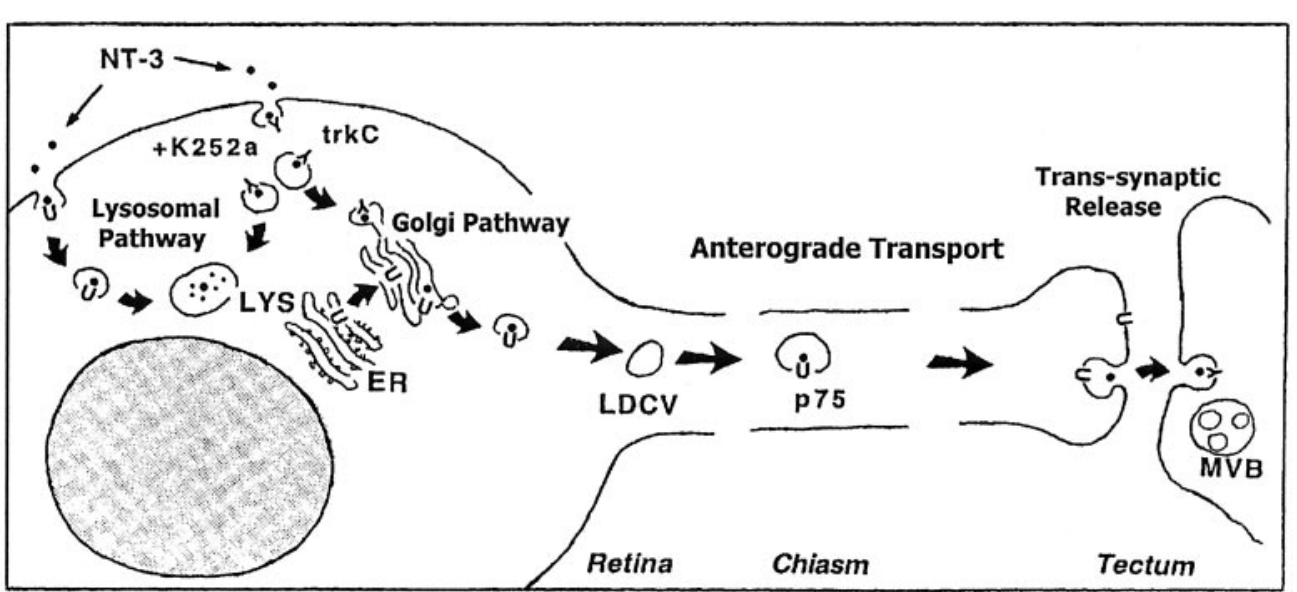

Figure 8. Diagram summarizing proposed subcellular pathways of internalized NT-3 (black dots) in a retinal ganglion cell. At least two pathways of internalized NT-3 can be distinguished. A lysosomal pathway of NT-3 may be common to all neurotrophins and may involve binding to the p75 receptor $(U)$ or binding of NT-3 to trkC receptor $(Y)$ in the presence of the tyrosine kinase inhibitor K252a. The neurotrophin is degraded in lysosomes $(L Y S)$. Alternatively, a novel pathway of NT-3 internalized in endosomes fuses with membranes of the Golgi apparatus: Golgi Pathway. This sorting requires tyrosine kinase activity (presumably $\operatorname{trk} C, Y$ ), and this pathway may join that of newly synthesized neurotrophins as well as p75 receptor $(U)$ from the endoplasmic reticulum $(E R)$ via the Golgi into an anterograde axonal path (von Bartheld et al., 2001). After passage through the Golgi system, internalized NT-3 is packaged in presumptive large dense-core vesicles ( $L D C V$ ) (Wang et al., 2001) for anterograde axonal transport. In this pathway, internalized NT-3 binds preferentially to p75. Anterogradely transported NT-3 is released from RGC axon terminals in the tectum, and after release it binds predominantly to trkC in tectal cells where it accumulates in multivesicular bodies (MVB) (von Bartheld et al., 1996a).

neurotrophin binding to the 10,000 isthmo-optic nerve fibers (Clarke et al., 1976), as opposed to the $2.5 \times 10^{6}$ RGC fibers in the optic nerve (Rager, 1980). Injection of monensin in the eye abolishes anterograde transport of neurotrophins but leaves retrograde axonal transport via isthmo-optic fibers undisturbed (von Bartheld et al., 1996b). When monensin was coinjected, NT-3 binding to receptors in the isthmo-optic fibers was similar to the NT-3 binding for combined RGC fibers + isthmo-optic fibers in the chiasm (data not shown). Because the isthmo-optic nucleus contributes $<10 \%$ of the total axonal transport of neurotrophins from the retina to the brain, as revealed by coinjection experiments with monensin (von Bartheld et al., 1996b), the ratios observed would be minimally altered because of "contamination" by $\sim 0.5 \%$ isthmo-optic fibers among $99.5 \%$ RGC fibers in the optic nerve.

In conclusion, the receptor binding data suggest intriguing dynamics of receptor association and dissociation, namely the initial binding of NT-3 to trkC in the RGC cell body, followed by trafficking in which trkC binding is diminished and p75 binding is increased. This likely represents the fusion of trkC endosomes with p75-containing membranes in the Golgi. The subsequently increased binding of NT-3 to trkC in the tectum is likely caused by the binding of NT-3 to trkC after its release from RGC terminals, uptake into tectal neurons, and accumulation in MVBs (von Bartheld et al., 1996a). The proposed model of NT-3 trafficking in RGCs and in the retinotectal projection is schematically summarized in Figure 8.

\section{DISCUSSION}

The subcellular distribution and pathways of internalized neurotrophins, NGF, BDNF, and NT-3, were examined and compared in RGCs. Internalized BDNF and NT-3 can follow a novel pathway into the Golgi apparatus, not previously described for trophic factors in neurons, and this pathway correlates with anterograde axonal transport. Tyrosine kinase activity is required for sorting into this pathway, but not for internalization. Rather than being rapidly degraded after internalization, a significant fraction of exogenous NT-3 is targeted within neurons and recycled for further uses.

\section{Internalization of neurotrophins: roles of receptors}

All three internalized neurotrophins accumulated in MVBs and endosomes. This is remarkable for NGF, because chick RGCs do not possess trkA receptors (Karlsson et al., 1998), indicating that NGF was internalized by the p75 receptor, as shown previously for glial cells (Kahle and Hertel, 1992). There were significant subcellular differences in the labeling densities between neurotrophins. BDNF and NGF accumulated at the plasma membrane, indicating retention, a slower internalization, or possibly recycling of these neurotrophins after internalization (Eveleth and Bradshaw, 1988, 1992). By contrast, NT-3 was conspicuously absent from the plasma membrane (Tables 1, 2). NT-3 may be more efficiently or rapidly internalized than BDNF and NGF, or may lack a recycling pathway to the cell surface membrane. Consistent with previous studies, internalized NGF did not accumulate in the Golgi system (Schwab and Thoenen, 1977; Claude et al., 1982; Bernd and Greene, 1983; Stieber et al., 1984). Although NT-3 can bind to trkB (Squinto et al., 1991; Farinas et al., 1998), NT-3 appears to be internalized predominantly by the trkC receptor in chick RGCs, although some contribution of trkB or p75 cannot be ruled out.

\section{Internalized NT-3 accumulates in a novel Golgi pathway in RGCs}

It is remarkable that internalized NT-3, and to a lesser extent BDNF, was abundant in the Golgi apparatus of RGCs (up to $20 \%$ ), with a peak at $10 \mathrm{hr}$ after injection (Fig. $6 \mathrm{~A}$ ). At this time point, NT-3 would be expected to concentrate in the Golgi apparatus before being moved by anterograde axonal transport to the tectum where it maximally accumulates $20 \mathrm{hr}$ after injection (von Bartheld et al., 1996a). Although we do not have direct proof that the Golgi-sorted NT-3 is the one that will be anterogradely transported, our data are consistent with this notion: correlations of Golgi passage and anterograde transport between neurotrophins, and with inhibitors such as brefeldin A and K252a (Figs. $1 B, 6 A)$. Newly synthesized proteins require passing through the Golgi apparatus before anterograde axonal transport (Hammerschlag et al., 1982). Toxins and other receptor ligands follow an endocytic recycling pathway from the plasma membrane to the Golgi (Joseph et al., 1978; Sandvig and van Deurs, 1996; Mukherjee et al., 1997), and this pathway seems to be particularly prominent in secretory cells (Green and Kelly, 1992; Hurtley, 1993; Pavelka et al., 1998). Our data indicate that the same endocytic Golgi pathway is used by internalized NT-3 in RGCs, thus demonstrating for the first time that neurotrophic factors follow 
this pathway as predicted (Hemar et al., 1997). This may be a common trafficking and recycling pathway among neurotrophic factors in neural circuits (von Bartheld et al., 2001). Internalized neurotrophins may merge with secretion pathways of newly synthesized neurotrophins, or there may exist two parallel pathways, one for newly synthesized and one for recycled neurotrophins. It is currently controversial whether regulated release is restricted to BDNF among the neurotrophins (Blöchl and Thoenen, 1995; Goodman et al., 1996; Heymach et al., 1996; Griesbeck et al., 1999; Mowla et al., 1999; Farhadi et al., 2000; von Bartheld et al., 2001; Wang et al., 2001).

\section{Sorting of internalized NT-3 between the lysosomal and the Golgi pathway by trkC activity}

After internalization by surface receptors, NT-3 is sorted into at least two distinct pathways (Fig. 8), either via presumptive endosomes/MVBs into lysosomes (degradation) or via presumptive endosomes into the Golgi apparatus and subsequent anterograde axonal transport to the nerve terminals (recycling). Treatment with K252a largely reduced anterograde transport of internalized NT-3 and diverted NT-3 away from the Golgi pathway into the lysosomal pathway (Fig. 6A,B). Our data implicate tyrosine kinase activity, and in particular trkC kinase activity, as a sorting signal for internalized NT-3. Coexpression and interactions of p75 and trk receptors seem to complexly alter internalization as well as intracellular pathways of neurotrophins (Eveleth and Bradshaw, 1992; Gargano et al., 1997). The mechanisms of sorting of internalized proteins are an area of intense research. Potential sorting signals include signal sequences, acidification, and tyrosine kinase activity (Felder et al., 1990; Bos et al., 1993; Chapman and Munro, 1994; Mukherjee et al., 1997). Our data indicate that tyrosine kinase activity is involved in one of the major sorting steps, possibly by exposing cryptic sorting signal sequences (Opresko et al., 1995).

\section{Binding to receptors after internalization and during anterograde trafficking of neurotrophins}

Very little is known about receptor binding of internalized neurotrophins (Rakowicz-Szulczynska et al., 1989) and particularly during anterograde axonal transport. Will neurotrophins remain bound to their receptors during axonal transport, or will they dissociate from receptors during vesicular transport? In glial cells, some of the endocytosed BDNF remains associated with truncated trkB (Alderson et al., 2000). By immunoprecipitating crosslinked neurotrophins during anterograde axonal transport with antibodies to neurotrophin receptors, we show that a significant fraction of internalized neurotrophins binds to receptors, and that the dynamics of receptor association and dissociation during membrane trafficking and sorting are surprisingly complex. NT-3 appears to internalize predominantly via trkC in RGCs, as evidenced by the almost exclusive precipitation of NT-3 with trkC antibodies in purified ganglion cell bodies (Fig. $7 C$ ) and lack of competition with heterologous neurotrophins (Fig. 1A). After sorting into the anterograde axonal transport, however, a significant fraction of the NT-3 becomes associated with p75 (Fig. 7A), possibly after merging of trkC-endosome membranes with p75containing Golgi membranes. "Free" trkC on early endosome membranes may recycle back to the plasma membrane, as described for many surface receptors (Mukherjee et al., 1997), whereas dissociated NT-3 may bind to p75 receptors in Golgi membranes that are destined for anterograde axonal transport in RGCs. P75 receptors are anterogradely transported by chick
RGCs (von Bartheld and Butowt, 2000). After release from retinotectal terminals, NT-3 appears to bind preferentially to trkC, which is expressed by tectal neurons in the superficial optic tectum (von Bartheld et al., 1996a). Anterogradely transported NT-3 in the tectum likely has multiple functions, including neuron survival (von Bartheld et al., 1996a), neurite branching (Inoue and Sanes, 1997), and synaptic plasticity (Wang et al., 2000).

\section{Are internalized neurotrophins in RGCs intact?}

Internalized NGF is rapidly degraded in neurons and PC12 cells (Johnson et al., 1978; Eveleth and Bradshaw, 1992; Ure and Campenot, 1997), yet neurotrophins transcytosed by intestinal epithelial cells or glial cells remain intact (Siminoski et al., 1986; Rubio, 1997; Alderson et al., 2000). Exogenous NT-3 and BDNF arrive in the tectum intact after transcytosis of RGCs (von Bartheld et al., 1996a; von Bartheld and Johnson, 2001). Our study shows surprising differences in the susceptibility of neurotrophins to cleavage after internalization in RGCs (Fig. 6D). Most of the BDNF, but not NGF or NT-3, was cleaved, possibly because of a 10 min exposure to trypsin during the dissociation for RGC purification. These data may indicate that BDNF rapidly recycles to the cell surface (where $20 \%$ of the BDNF accumulates) (Table 2), so that most of the BDNF was cleaved by trypsin, indicating a rapid turnover of the trkB receptor. Indeed, neurotrophin receptors (NGF receptors and trkB) rapidly recycle to the cell surface with half-lives on the order of minutes (Eveleth and Bradshaw, 1988; Grimes et al., 1996), presumably by trafficking within presumptive endosomes (Meyer-Franke et al., 1998; Du et al., 2000). Rapid recycling of neurotrophin receptors to the plasma membrane may regulate receptor densities and thus trophic responsiveness.

\section{Implications for recycling of neurotrophins and therapeutic uses}

The possibility of recycling and transcytosis of endogenous and exogenous neurotrophins in the CNS has received little attention (von Bartheld et al., 2001), yet this feature may have important functions for the normal physiology of neural circuits. Neurotrophins may follow different subcellular pathways and thus activate different signaling pathways, e.g., survival versus neuritogenesis (Saragovi et al., 1998; Zhang et al., 2000). Transcytosis of neurotrophins may also explain mismatches between neurotrophin transcript and protein levels (Nawa et al., 1995). Anterograde trafficking of BDNF in the adult CNS may be more prevalent than retrograde trafficking (Conner et al., 1998), and some of this trafficking may constitute physiological transcytosis (Spalding et al., 1999; Caleo et al., 2000). TrkB receptors on cortical neurons are essential for the maintenance of functional dendritic morphology and the survival of these neurons (Xu et al., 2000). Degenerative neuronal diseases may be caused by insufficient or misdirected neurotrophins (Saper et al., 1987), and targeting of neurotrophins to their proper destinations may prevent or alleviate trophic deficits. Once the mechanisms of targeting of neurotrophins to their subcellular destinations are better understood, it may be possible to manipulate trafficking of endogenous and exogenous neurotrophins and target them to alleviate neuronal dysfunction and degenerative diseases (Caleo et al., 2000).

\section{REFERENCES}

Alderson RF, Curtis R, Alterman AL, Lindsay RM, DiStefano PS (2000) Truncated TrkB mediates the endocytosis and release of BDNF and neurotrophin- $4 / 5$ by rat astrocytes and Schwann cells in vitro. Brain Res 871:210-222.

Barker PA, Murphy RA (1992) The nerve growth factor receptor: a 
multicomponent system that mediates the actions of the neurotrophin family of proteins. Mol Cell Biochem 110:1-15.

Bartlett SE, Reynolds AJ, Weible M, Heydon K, Hendry IA (1997) In sympathetic but not sensory neurones, phosphoinositide-3 kinase is important for NGF-dependent survival and the retrograde transport of ${ }^{125}$ I-betaNGF. Brain Res 761:257-262.

Bernd P, Greene LA (1983) Electron microscopic radioautographic localization of iodinated nerve growth factor bound to and internalized by PC12 cells. J Neurosci 3:631-643.

Bernd P, Greene LA (1984) Association of $\left[{ }^{125} \mathrm{I}\right]$ nerve growth factor with PC12 pheochromocytoma cells. Evidence for internalization via high-affinity receptors only and for long-term regulation by nerve growth factor of both high- and low-affinity receptors. J Biol Chem 259:15509-15516.

Blöchl A, Thoenen H (1995) Characterization of nerve growth factor (NGF) release from hippocampal neurons: evidence for a constitutive and an unconventional sodium-dependent regulated pathway. Eur J Neurosci 7:1220-1228.

Bos K, Wraight C, Stanley KK (1993) TGN38 is maintained in the trans-Golgi network by a tyrosine-containing motif in the cytoplasmic domain. EMBO J 12:2219-2228

Bothwell M (1995) Functional interactions of neurotrophins and neurotrophin receptors. Annu Rev Neurosci 18:223-253.

Butowt R, von Bartheld CS (2000) Sorting of internalized neurotrophins by trk kinase activity: ultrastructural analysis in retinal ganglion cells. Soc Neurosci Abstr 26:843.

Butowt R, Jeffrey PL, von Bartheld CS (2000) Purification of chick retinal ganglion cells for molecular analysis: combining retrograde labeling and immunopanning yields 100\% purity. J Neurosci Methods 95:29-38.

Caleo M, Menna E, Chierzi S, Cenni MC, Maffei L (2000) Brainderived neurotrophic factor is an anterograde survival factor in the rat visual system. Curr Biol 10:1155-1161.

Caro LG, van Tubergen RP (1962) High resolution autoradiography. I. Methods. J Cell Biol 15:173-188.

Chapman RE, Munro S (1994) Retrieval of TGN proteins from the cell surface requires endosomal acidification. EMBO J 13:2305-2312.

Clarke PG, Rogers LA, Cowan WM (1976) The time of origin and the pattern of survival of neurons in the isthmo-optic nucleus of the chick. J Comp Neurol 167:125-142.

Claude P, Hawrot E, Dunis DA, Campenot RB (1982) Binding, internalization, and retrograde transport of ${ }^{125} \mathrm{I}$-nerve growth factor in cultured rat sympathetic neurons. J Neurosci 2:431-442.

Conner JM, Lauterborn JC, Gall CM (1998) Anterograde transport of neurotrophin proteins in the CNS: a reassessment of the neurotrophic hypothesis. Rev Neurosci 9:91-103.

Curtis R, Adryan KM, Stark JL, Park JS, Campton DL, Weskamp G, Huber LJ, Chao MV, Jaenisch R, Lee KF, Lindsay RM, DiStefano PS (1995) Differential role of the low-affinity neurotrophin receptor (p75) in retrograde axonal transport of the neurotrophins. Neuron 14:1201-1211.

Das I, Hempstead BL, MacLeish PR, Sparrow JR (1997) Immunohistochemical analysis of the neurotrophins BDNF and NT-3 and their receptors trkB, trkC, and $\mathrm{p} 75$ in the developing chick retina. Vis Neurosci 14:835-842.

DiStefano PS, Friedman B, Radziejewski C, Alexander C, Boland P, Schick CM, Lindsay RM, Wiegand SJ (1992) The neurotrophins BDNF, NT-3, and NGF display distinct patterns of retrograde axonal transport in peripheral and central neurons. Neuron 8:983-993.

Du J, Feng L, Yang F, Lu B (2000) Activity- and Ca(2+)-dependent modulation of surface expression of brain-derived neurotrophic factor receptors in hippocampal neurons. J Cell Biol 150:1423-1434.

Ehrlich D (1981) Regional specialization of the chick retina as revealed by the size and density of neurons in the ganglion cell layer. J Comp Neurol 195:643-657.

Escandon E, Burton LE, Szonyi E, Nikolics K (1993) Characterization of neurotrophin receptors by affinity cross-linking. J Neurosci Res 34:601-613.

Eveleth DD, Bradshaw RA (1988) Internalization and cycling of nerve growth factor in PC12 cells: interconversion of type II (fast) and type I (slow) nerve growth factor receptors. Neuron 1:929-936.

Eveleth DD, Bradshaw RA (1992) Nerve growth factor nonresponsive pheochromocytoma cells: altered internalization results in signaling dysfunction. J Cell Biol 117:291-299.

Farhadi HF, Mowla SJ, Petrecca K, Morris SJ, Seidah NG, Murphy RA (2000) Neurotrophin-3 sorts to the constitutive secretory pathway of hippocampal neurons and is diverted to the regulated secretory pathway by coexpression with brain-derived neurotrophic factor. J Neurosci 20:4059-4068.

Farinas I, Wilkinson GA, Backus C, Reichardt LF, Patapoutian A (1998) Characterization of neurotrophin and Trk receptor functions in developing sensory ganglia: direct NT-3 activation of TrkB neurons in vivo. Neuron 21:325-334.

Fawcett JP, Aloyz R, McLean JH, Pareek S, Miller FD, McPherson PS, Murphy RA (1997) Detection of brain-derived neurotrophic factor in a vesicular fraction of brain synaptosomes. J Biol Chem 272:8837-8840.
Felder S, Miller K, Moehren G, Ullrich A, Schlessinger J, Hopkins CR (1990) Kinase activity controls the sorting of the epidermal growth factor receptor within the multivesicular body. Cell 61:623-634.

Ferguson IA, Schweitzer JB, Johnson Jr EM (1990) Basic fibroblast growth factor: receptor-mediated internalization, metabolism, and anterograde transport in retinal ganglion cells. J Neurosci 10:2176-2189.

French PW, Jeffrey PL (1986) Partial characterization of chicken Thy-1 glycoprotein by monoclonal antibodies. J Neurosci Res 16:479-489.

Gallo G, Letourneau PC (1998) Localized sources of neurotrophins initiate axon collateral sprouting. J Neurosci 18:5403-5414.

Gargano N, Levi A, Alema S (1997) Modulation of nerve growth factor internalization by direct interaction between p75 and TrkA receptors. J Neurosci Res 50:1-12.

Garner AS, Menegay HJ, Boeshore KL, Xie X-Y, Voci JM, Johnson JE, Large TH (1996) Expression of trkB receptor isoforms in the developing avian visual system. J Neurosci 16:1740-1752.

Goodman LJ, Valverde J, Lim F, Geschwind MD, Federoff HJ, Geller AI, Hefti F (1996) Regulated release and polarized localization of brain-derived neurotrophic factor in hippocampal neurons. Mol Cell Neurosci 7:222-238.

Green SA, Kelly RB (1992) Low density lipoprotein receptor and cation-independent mannose 6-phosphate receptor are transported from the cell surface to the Golgi apparatus at equal rates in PC12 cells. J Cell Biol 117:47-55.

Griesbeck O, Canossa M, Campana G, Gartner A, Hoener MC, Nawa H, Kolbeck R, Thoenen H (1999) Are there differences between the secretion characteristics of NGF and BDNF? Implications for the modulatory role of neurotrophins in activity-dependent neuronal plasticity. Microsc Res Tech 45:262-275.

Grimes ML, Zhou J, Beattie EC, Yuen EC, Hall DE, Valletta JS, Topp KS, LaVail JH, Bunnett NW, Mobley WC (1996) Endocytosis of activated TrkA: evidence that nerve growth factor induces formation of signaling endosomes. J Neurosci 16:7950-7964.

Hallböök F, Bäckström A, Kullander K, Ebendal T (1996) Expression of neurotrophins and trk receptors in the avian retina. J Comp Neurol 364:664-676.

Hamburger V, Hamilton H (1951) A series of normal stages in the development of the chick embryo. J Morphol 88:49-92.

Hammerschlag R, Stone GC, Bolen FA, Lindsey JD, Ellisman MH (1982) Evidence that all newly synthesized proteins destined for axonal transport pass through the Golgi apparatus. J Cell Biol 93:568-575.

Hemar A, Olivo JC, Williamson E, Saffrich R, Dotti CG (1997) Dendroaxonal transcytosis of transferrin in cultured hippocampal and sympathetic neurons. J Neurosci 17:9026-9034.

Herzog KH, von Bartheld CS (1998) Contributions of the optic tectum and the retina as sources of brain-derived neurotrophic factor for retinal ganglion cells in the chick embryo. J Neurosci 18:2891-2906.

Heuer JG, Fatemie-Nainie S, Wheeler EF, Bothwell M (1990) Structure and developmental expression of the chicken NGF receptor. Dev Biol 137:287-304.

Heymach JV, Krüttgen A, Suter U, Shooter EM (1996) The regulated secretion and vectorial targeting of neurotrophins in neuroendocrine and epithelial cells. J Biol Chem 271:25430-25437.

Hogue-Angeletti R, Stieber A, Gonatas NK (1982) Endocytosis of nerve growth factor by PC12 cells studied by quantitative ultrastructural autoradiography. Brain Res 241:145-156.

Hunziker W, Whitney JA, Mellman I (1991) Selective inhibition of transcytosis by brefeldin A in MDCK cells. Cell 67:617-627.

Hurtley SM (1993) Recycling of a secretory granule membrane protein after stimulated secretion. J Cell Sci 106:649-655.

Inoue A, Sanes JR (1997) Lamina-specific connectivity in the brain: regulation by $\mathrm{N}$-cadherin, neurotrophins, and glycoconjugates. Science 276:1428-1431.

Johnson Jr EM, Andres RY, Bradshaw RA (1978) Characterization of the retrograde transport of nerve growth factor (NGF) using high specific activity [ $\left.{ }^{125} \mathrm{I}\right] \mathrm{NGF}$. Brain Res 150:319-331.

Joseph KC, Kim SU, Stieber A, Gonatas NK (1978) Endocytosis of cholera toxin into neuronal GERL. Proc Natl Acad Sci USA 75:2815-2819.

Kahle P, Hertel C (1992) Nerve growth factor (NGF) receptor on rat glial cell lines. Evidence for NGF internalization via p75NGFR. J Bio Chem 267:13917-13923.

Kahle P, Barker PA, Shooter EM, Hertel C (1994) p75 nerve growth factor receptor modulates p140trkA kinase activity, but not ligand internalization, in PC12 cells. J Neurosci Res 38:599-606.

Kaplan DR, Miller FD (2000) Neurotrophin signal transduction in the nervous system. Curr Opin Neurobiol 10:381-391.

Karlsson M, Clary DO, Lefcort FB, Reichardt LF, Karten HJ, Hallböök F (1998) Nerve growth factor receptor TrkA is expressed by horizontal and amacrine cells during chicken retinal development. J Comp Neurol 400:408-416.

Knusel B, Hefti F (1992) K-252 compounds: modulators of neurotrophin signal transduction. J Neurochem 59:1987-1996.

Kullander K, Mather NK, Diella F, Dottori M, Boyd AW, Klein R 
(2001) Kinase-dependent and kinase-independent functions of EphA4 receptors in major axon tract formation in vivo. Neuron 29:73-84.

Layer PG, Shooter EM (1983) Binding and degradation of nerve growth factor by PC12 pheochromocytoma cells. J Biol Chem 258:3012-3018.

Lefcort F, Clary DO, Rusoff AC, Reichardt LF (1996) Inhibition of the NT-3 receptor TrkC, early in chick embryogenesis, results in severe reductions in multiple neuronal subpopulations in the dorsal root ganglia. J Neurosci 16:3704-3713.

Lippincott-Schwartz J, Yuan L, Tipper C, Amherdt M, Orci L, Klausner RD (1991) Brefeldin A's effects on endosomes, lysosomes, and the TGN suggest a general mechanism for regulating organelle structure and membrane traffic. Cell 67:601-616.

Mallet WG, Maxfield FR (1999) Chimeric forms of furin and TGN38 are transported with the plasma membrane in the trans-Golgi network via distinct endosomal pathways. J Cell Biol 146:345-359.

Mercanti D, Butler R, Revoltella R (1977) A tryptic digestion fragment of nerve growth factor with nerve growth promoting activity. Biochim Biophys Acta 496:412-419.

Meyer-Franke A, Wilkinson GA, Krüttgen A, Hu M, Munro E, Hanson Jr MG, Reichardt LF, Barres BA (1998) Depolarization and cAMP elevation rapidly recruit TrkB to the plasma membrane of CNS neurons. Neuron 21:681-693.

Michael GJ, Averill S, Nitkunan A, Rattray M, Bennett DL, Yan Q, Priestley JV (1997) Nerve growth factor treatment increases brainderived neurotrophic factor selectively in TrkA-expressing dorsal root ganglion cells and in their central terminations within the spinal cord. J Neurosci 17:8476-8490.

Mowla SJ, Pareek S, Farhadi HF, Petrecca K, Fawcett JP, Seidah NG, Morris SJ, Sossin WS, Murphy RA (1999) Differential sorting of nerve growth factor and brain-derived neurotrophic factor in hippocampal neurons. J Neurosci 19:2069-2080.

Mukherjee S, Ghosh RN, Maxfield FR (1997) Endocytosis. Physiol Rev 77:759-803.

Nawa H, Carnahan J, Gall C (1995) BDNF protein measured by a novel enzyme immunoassay in normal brain and after seizure: partial disagreement with mRNA levels. Eur J Neurosci 7:1527-1535.

Nixon RA, Cataldo AM (1995) The endosomal-lysosomal system of neurons: new roles. Trends Neurosci 18:489-496.

Opresko LK, Chang CP, Will BH, Burke PM, Gill GN, Wiley HS (1995) Endocytosis and lysosomal targeting of epidermal growth factor receptors are mediated by distinct sequences independent of the tyrosine kinase domain. J Biol Chem 270:4325-4333.

Pavelka M, Ellinger A, Debbage P, Loewe C, Vetterlein M, Roth J (1998) Endocytic routes to the Golgi apparatus. Histochem Cell Biol 109:555-570.

Prada FA, Chmielewski CE, Dorado ME, Prada C, Genisgalvez JM (1989) Displaced ganglion-cells in the chick retina. Neurosci Res 6:329-339.

Rager GH (1980) Development of the retinotectal projection in the chicken. Adv Anat Embryol Cell Biol 63:1-90.

Rakowicz-Szulczynska EM, Linnenbach AJ, Koprowski H (1989) Intracellular receptor binding and nuclear transport of nerve growth factor in intact cells and a cell-free system. Mol Carcinog 2:47-58.

Riccio A, Pierchala BA, Ciarallo CL, Ginty DD (1997) An NGF-TrkAmediated retrograde signal to transcription factor CREB in sympathetic neurons. Science 277:1097-1100.

Rodriguez-Tebar A, Dechant G, Gotz R, Barde YA (1992) Binding of neurotrophin-3 to its neuronal receptors and interactions with nerve growth factor and brain-derived neurotrophic factor. EMBO J 11:917-922.

Rohrer H, Schafer T, Korsching S, Thoenen H (1982) Internalization of nerve growth factor by pheochromocytoma PC12 cells: absence of transfer to the nucleus. J Neurosci 2:687-697.

Rubio N (1997) Mouse astrocytes store and deliver brain-derived neurotrophic factor using the non-catalytic gp95trkB receptor. Eur J Neurosci 9:1847-1853.

Salpeter MM, McHenry FA, Salpeter EE (1978) Resolution of electron microscope autoradiography. IV. Application to analysis of autoradiographs. J Cell Biol 76:127-145.

Sandvig K, van Deurs B (1996) Endocytosis, intracellular transport, and cytotoxic action of Shiga toxin and ricin. Physiol Rev 76:949-966.

Saper CB, Wainer BH, German DC (1987) Axonal and transneuronal transport in the transmission of neurological disease: potential role in system degenerations, including Alzheimer's disease. Neuroscience 23:389-398.

Saragovi HU, Zheng W, Maliartchouk S, DiGugliemo GM, Mawal YR, Kamen A, Woo SB, Cuello AC, Debeir T, Neet KE (1998) A TrkAselective, fast internalizing nerve growth factor-antibody complex induces trophic but not neuritogenic signals. J Biol Chem 273:34933-34940.

Schwab M, Thoenen H (1977) Selective trans-synaptic migration of tetanus toxin after retrograde axonal transport in peripheral sympathetic nerves: a comparison with nerve growth factor. Brain Res 122:459-474.

Segal RA, Greenberg ME (1996) Intracellular signaling pathways activated by neurotrophic factors. Annu Rev Neurosci 19:463-489.
Shitara Y, Kato Y, Sugiyama Y (1998) Effect of brefeldin A and lysosomotropic reagents on intracellular trafficking of epidermal growth factor and transferrin in Madin-Darby canine kidney epithelial cells. J Control Release 55:35-43.

Siminoski K, Gonnella P, Bernanke J, Owen L, Neutra M, Murphy RA (1986) Uptake and transepithelial transport of nerve growth factor in suckling rat ileum. J Cell Biol 103:1979-1990.

Spalding KL, Tan MML, Hendry IA, Harvey AL (1999) Cell death and the transport of neurotrophins in the rat visual system. Soc Neurosci Abstr 25:767.

Squinto SP, Stitt TN, Aldrich TH, Davis S, Bianco SM, Radziejewski C, Glass DJ, Masiakowski P, Furth ME, Valenzuela DM, DiStefano PS, Yancopoulos GD (1991) TrkB encodes a functional receptor for brain-derived neurotrophic factor and neurotrophin-3 but not nerve growth factor. Cell 65:885-893.

Stieber A, Hickey WF, Hogue-Angeletti R, Gonatas NK (1984) Endocytosis of nerve growth factor by "differentiated" PC12 cells studied by quantitative ultrastructural autoradiography. Brain Res 310:223-234.

Taniuchi M, Johnson Jr EM (1985) Characterization of the binding properties and retrograde axonal transport of a monoclonal antibody directed against the rat nerve growth factor receptor. J Cell Biol 101:1100-1106.

Ure DR, Campenot RB (1997) Retrograde transport and steady-state distribution of ${ }^{125}$ I-nerve growth factor in rat sympathetic neurons in compartmented cultures. J Neurosci 17:1282-1290.

Vale RD, Shooter EM (1985) Assaying binding of nerve growth factor to cell surface receptors. Methods Enzymol 109:21-39.

Vlahos CJ, Matter WF, Hui KY, Brown RF (1994) A specific inhibitor of phosphatidylinositol 3-kinase, 2-(4-morpholinyl)-8-phenyl-4H-1benzopyran-4-one (LY294002). J Biol Chem 269:5241-5248.

von Bartheld CS (1996) Identification of the receptors which bind the neurotrophins BDNF and NT-3 during retrograde and anterograde axonal transport. Soc Neurosci Abstr 22:1002.

von Bartheld CS (1998a) Neurotrophins in the developing and regenerating visual system. Invited review. Histol Histopathol 13:437-459.

von Bartheld CS (1998b) Radio-iodination of neurotrophins and their delivery in vivo: advantages of membrane filtration and the use of disposable syringes. J Neurosci Methods 79:207-733.

von Bartheld CS (2001) Tracing with radiolabeled neurotrophins. Methods Mol Biol 169:195-216.

von Bartheld CS, Butowt R (2000) Expression of neurotrophin-3 (NT-3) and anterograde axonal transport of endogenous NT-3 by retinal ganglion cells in chick embryos. J Neurosci 20:736-748.

von Bartheld CS, Johnson JE (2001) Target-derived BDNF (brainderived neurotrophic factor) is essential for the survival of developing neurons in the isthmo-optic nucleus. J Comp Neurol 433:550-564.

von Bartheld CS, Heuer JG, Bothwell M (1991) Expression of nerve growth factor (NGF) receptors in the brain and retina of chick embryos: comparison with cholinergic development. J Comp Neurol 310:103-129.

von Bartheld CS, Byers MR, Williams R, Bothwell M (1996a) Anterograde transport and axo-dendritic transfer of neurotrophins in the developing visual system. Nature 379:830-833.

von Bartheld CS, Williams R, Lefcort F, Clary DO, Reichardt LF, Bothwell M (1996b) Retrograde transport of neurotrophins from the eye to the brain in chick embryos: roles of the p75 ${ }^{\text {NTR }}$ and trkB receptors. J Neurosci 16:2995-3008.

von Bartheld CS, Wang XX, Butowt R (2001) Anterograde transport, transcytosis, and recycling of neurotrophic factors: the concept of trophic currencies in neural networks. Invited review. Mol Neurobiol, in press.

Wang XX, Butowt R, von Bartheld CS (2000) Effects of NT-3 on the number, size and vesicle density of retinotectal synapses in chick embryos. Soc Neurosci Abstr 26:843.

Wang XX, Butowt R, Vasko MR, von Bartheld CS (2001) Mechanisms of the release of anterogradely transported neurotrophin 3 from presynaptic axon terminals. $\mathrm{J}$ Neurosci, in press.

Weskamp G, Reichardt LF (1991) Evidence that biological activity of NGF is mediated through a novel subclass of high affinity receptors. Neuron 6:649-663.

Xu B, Zang K, Ruff NL, Zhang YA, McConnell SK, Stryker MP, Reichardt LF (2000) Cortical degeneration in the absence of neurotrophin signaling: dendritic retraction and neuronal loss after removal of the receptor TrkB. Neuron 26:233-245.

York RD, Molliver DC, Grewal SS, Stenberg PE, McCleskey EW, Stork PJ (2000) Role of phosphoinositide 3-kinase and endocytosis in nerve growth factor-induced extracellular signal-regulated kinase activation via Ras and Rapl. Mol Cell Biol 20:8069-8083.

Zhang Y, Moheban DB, Conway BR, Bhattacharyya A, Segal RA (2000) Cell surface Trk receptors mediate NGF-induced survival while internalized receptors regulate NGF-induced differentiation. J Neurosci 20:5671-5678. 